
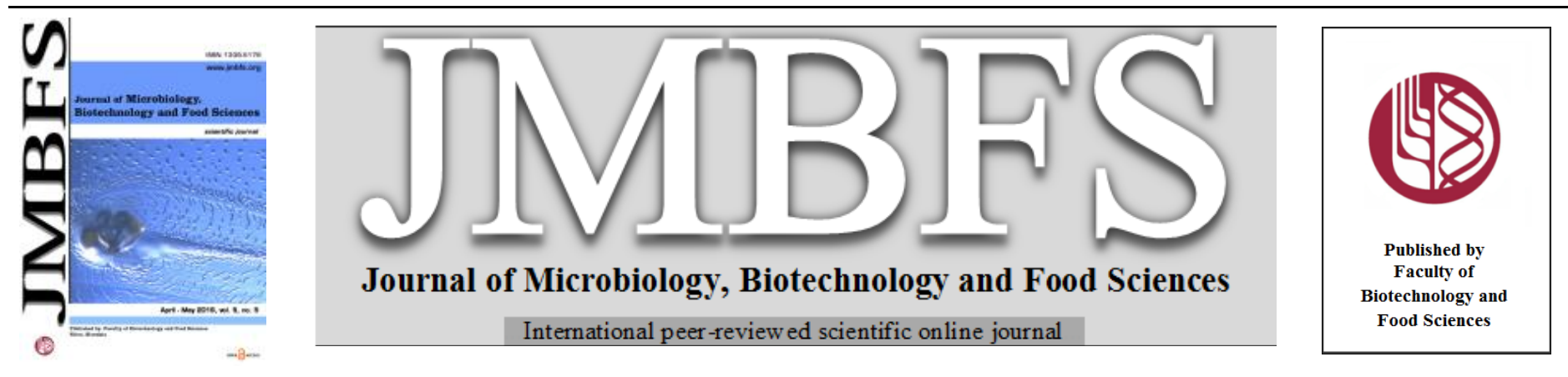

\title{
STATISTICAL APPROACH FOR PECTINASE PRODUCTION BY Bacillus firmus SDB9 AND EVALUATION OF PECTINO-XYLANOLYTIC ENZYMES FOR PRETREATMENT OF KRAFT PULP
}

\author{
Divyesh D. Bhagat*, Pravin R. Dudhagara and Piyush V. Desai \\ Address(es): Department of Biosciences, Veer Narmad South Gujarat University, Surat-395007, India.
}

*Corresponding author: divyeshbhagat007@gmail.com

doi: 10.15414/jmbfs.2016.5.5.396-406

ARTICLE INFO

Received 22. 10. 2015

Revised 25. 12. 2015

Accepted 7. 1. 2016

Published 1. 4. 2016

Regular article open $O$ access

\begin{abstract}
The present study originated with the concomitant production of $1.94 \mathrm{IU} \cdot \mathrm{mL}^{-1}$ of pectinase, $0.34 \mathrm{IU} \cdot \mathrm{mL}^{-1}$ xylanase and $0.086 \mathrm{IU} \cdot \mathrm{mL}^{-1}$ cellulase from a newly isolated Bacillus firmus SDB9 in pectin salt media. Plackett-Burman Design (PBD) and Box-Behnken design (BBD) were used for optimization of mass production of pectinase using agro-residues. Statistical optimization of medium enhances the pectinase production to $17.55 \mathrm{IU} . \mathrm{mL}^{-1}, 17.7 \%$ higher activity than that of unoptimized medium. The optimal pectinase activity was found at $\mathrm{pH} 8.5$ and $45^{\circ} \mathrm{C}$ temperature. The enzyme was alkali-stable over a range of $\mathrm{pH} 7.0$ to 10.0 for $1 \mathrm{~h}$ and thermostable at 35 to $70^{\circ} \mathrm{C}$ for $1 \mathrm{~h}$. Out of 12 tested metal cations at $1 \mathrm{mM}$ concentration, the enzyme was found to be hindered by the presence of three cations, whereas four cations were reported to augment, and the rest marginally subdued the activity. Pretreatment with 15 IU pectinase and $2.7 \mathrm{IU}$ xylanase per gram of OD pulp reduce kappa number by $7.9 \%$. After bleaching sequence $\mathrm{D}_{0}-\mathrm{E}_{\mathrm{p}}-\mathrm{D}_{1}$, the increment in pulp brightness was $2.7 \%$ with acceptable whiteness level. Pretreatment also led to a reduction in $\mathrm{ClO}_{2}$ consumption by $15 \%$ with superior brightness level. The $0.83 \%$ increase in pulp viscosity along with $3.2 \%$ gain in double fold number indicated the maintenance of relative cellulose content and strength of paper. Minor variations in burst index, tensile index and tear index reflected the conserved properties of the treated pulp. Synergistic application of mixed enzymes preparation produced from raw agro-residue headed by pectinase in preference to xylanase is first time set forth in the present study to help in cost economization and propel the pulp and paper industries towards environmental friendly future.
\end{abstract}

\section{INTRODUCTION}

The pulp and paper industry uses an immense amount of hazardous chemicals to process inordinately high quantities of raw materials for the production of virgin pulp. Pulp and paper industries account for creating extremely high pollution in the environments globally (Sumathi and Hung, 2006; Thompson et al., 2001). Therefore, key attention has been to develop cost effective and environmentally benign bleaching technologies for a reduced adsorbable organic halogens (AOX) generation as many countries have now set discharge limits for these compounds in the generated effluents. With the progress in the field of biotechnology; enzymes have found their way into many new industrial processes. Enzymes are already well established in the processing of pulp and paper (Gavrilescu and Chisti, 2005). The earlier reports have shown interesting implications of the enzymes namely xylanase, pectinase, mannanase and laccase (Lahtinen $\boldsymbol{e t}$ al., 2009; Várnai et al., 2011) in pretreatment and processing of kraft pulp that collectively reduce the toxic discharge of pulp and paper industries.

Xylanase pretreatment of kraft pulp is already being employed across the globe with initial efforts by Viikari et al., (1986). However, the combined use of xylanase with pectinase prove a better option for treatment of Kraft pulp (Dhiman et al., 2009). Parenthetically the use of pectinase in the Kraft pulp pretreatment was proposed by Ahlawat et al., (2007). Since then the combination of xylanase with pectinase is being tried (Kaur et al., 2010). Nevertheless, Xylanase is the key enzyme in the kraft pulp pretreatment due to its significant role in the kappa number reduction, which reflects the lignin proportion due to its better penetration as a bleaching agent after removing hexenuronic acid from the pulp (Gangwar, Prakash, \& Prakash, 2014).In contrast, pectinase depolymerize polymers of galacturonic acids, and subsequently lower the cationic demand of pectin solutions and the filtrate from peroxide bleaching during paper making (Reid and Ricard, 2000; Viikari and Tenakanen, 2001). Hence, the combinatorial approach with the reverse proportion of xylanase and pectinase (where pectinase is more than xylanase) may serve as an innovative solution in kraft pulp pretreatment. Nonetheless, this area remains unexplored.
Production of xylanase from Bacillus species has been reported by several researchers (Ersayin et al., 2010; Nagar et al., 2010). Similarly, pectinase production from Bacillus species has also been reported (Basu et al., 2008; Sharma \& Satyanarayana, 2006). Moreover there is a single report on simultaneous production of xylano-pectinolytic mixture from the same strains of B. pumilus (Kaur et al., 2010) but there is no report available till date regarding simultaneous production of pectino-xylanolytic mixture from single strain of Bacillus. The possibility to use crude enzymes for pretreatment is the first and foremost step in reducing the cost of the process (Viikari et al.,1987; Viikari $\boldsymbol{e t}$ al., 1986). The second step is the cost-effective production of pectino-xylanolytic enzymes to improve the process economics of biobleaching at industrial scale. Pure substrates being highly expensive, it cannot be afforded at the industrial level bulk production of enzymes (Adhyaru et al., 2014). This goal can be achieved by employing a huge amount of residual plant biomass considered as waste. In Indian subcontinents, orange peel is massively generated waste agriresidues suitable for pectinase production. However, to use crude and raw substrates for the enzymes production, successful optimization of media is a prerequisite (Kumar et al., 2014). The traditional practice using OVAT approach is time consuming and cumbersome as against the statistical approach that additionally offers the analysis of interactive effects of various process parameters (Embaby et al., 2014).Response surface methodology is a wellaccepted statistical approach to enhance the enzyme yield though the magnitude of increase may vary (Ali et al., 2013). However, finally RSM renders the process more feasible at industrial scale.

Assessment of the bleaching potential of crude enzymes in terms of kappa number reduction and improvement in brightness is a well-established strategy (Choudhury et al., 2006). Moreover, the positive inputs in optical and strength properties of pulp and paper support the same. Several studies of the application of crude xylanase with pectinase in pulp bleaching have been reported, but the use of the high content of pectinase than xylanase was not being tried earlier that is presented herewith. 


\section{METHODOLOGY}

Isolation, Screening and Identification of pectinase and xylanase producer strain

A bacterial strain was isolated from soil samples contaminated with the effluen of an oil refinery, Digboi, Assam, India. The pooled soil samples were homogenized and serially diluted in sterile distilled water followed by plating on pectin agar medium containing pectin $5.0 \mathrm{~g} . \mathrm{L}^{-1}$ and yeast extract $1.0 \mathrm{~g} . \mathrm{L}^{-1}(\mathrm{pH}$ 8.0). All plates were incubated at $35 \pm 2.0^{\circ} \mathrm{C}$ for 24 to $72 \mathrm{~h}$. Morphologically distinct colony was purified by repeated streaking. Primary evaluation of poten bacterial strains for pectinase production was carried out by plate assay method (Wood et al., 1988) using nutrient agar supplemented with $0.5 \%$ w/v of pectin. The plates were incubated for the growth and then flooded with $1 \%$ CTAB Positive pectinase activity was detected by the clear zone surrounding the colonies. Similarly, the strains were screened for xylanase and cellulase activities using Bushnell-Haas medium containing 0.5\% w/v xylan and $1 \% \mathrm{w} / \mathrm{v}$ carboxymethyl cellulose (CMC) as a substrate. The plates were incubated for growth and stained with $1 \% \mathrm{w} / \mathrm{v}$ Congo red dye and destained with $1.0 \mathrm{M} \mathrm{NaCl}$ Positive xylanase and cellulase activities were detected by the presence of yellow halo against a red background. Potential strainSDB9 was identified based on 16S rRNA gene sequencing. The phylogenetic relationships with some reference strains were determined using the neighbor-joining method using Mega 5.0.

\section{Concurrent production of enzymes and growth profile}

Pectino-xylanolytic enzymes were produced under submerged fermentation in $250 \mathrm{~mL}$ Erlenmeyer flasks containing $100 \mathrm{~mL}$ of production medium consisting of Yeast extract $(0.1 \%),\left(\mathrm{NH}_{4}\right)_{2} \mathrm{SO}_{4}(0.2 \%), \mathrm{NA}_{2} \mathrm{HPO}_{4}(0.6 \%), \mathrm{KH}_{2} \mathrm{PO}_{4}(0.3 \%)$, $\mathrm{MgSO}_{4} .7 \mathrm{H}_{2} \mathrm{O}(0.1 \%), \mathrm{CaCl}_{2}(0.001 \%)$ and Pectin $(0.5 \%)$ as a sole carbon source $(\mathrm{pH} 8.0)$ incubated under shaking $(120 \mathrm{rpm})$ conditions at $40{ }^{\circ} \mathrm{C}$. After $48 \mathrm{~h}$, the fermented broth was centrifuged, and the cell-free supernatant was subjected to purification. The enzyme was partially purified by precipitation with ammonium sulfate and subsequent dialysis from the supernatant obtained by separating the biomass through refrigerated centrifugation at $10,000 \mathrm{~g}$ for $20 \mathrm{~min}$ and used for further studies.

\section{Enzyme assay}

The pectinase activity was assayed by measuring the amount of reducing sugar (xylose equivalent) liberated from polygalacturonic acid using 3, 5dinitrosalicylicacid (Miller, 1959). The xylanase activity was assayed according to the method of Bailey et al., (1992). Cellulase activity (carboxymethyl cellulase) was determined as per IUPAC method (Ghose, 1987). One unit (IU) of pectinase, xylanase and cellulase activities were defined as the amount of enzyme that catalyzed the release of 1.0 micro mol of reducing sugar as galacturonic acid, xylose and glucose equivalent per minute under the specified assay conditions respectively.

\section{Effect of nitrogen and crude pectin sources on pectinase production}

Three inorganic nitrogen sources $\mathrm{KNO}_{3}, \mathrm{NaNO}_{3}, \mathrm{NH}_{4} \mathrm{Cl}$ and three organic nitrogen sources peptone, yeast extract and casein at $0.5 \% \mathrm{w} / \mathrm{v}$ were studied for optimum enzyme production. A control lacking nitrogen source was run. The pectinase production was also tested by replacing $0.5 \% \mathrm{w} / \mathrm{v}$ pectin with agricultural materials viz. orange peel, hardwood bark, banana peel and jute in the production media. These agricultural waste materials were washed with distilled water and dried in sunlight and powdered. The lignocellulosic substrates were given pretreatment before using it in production medium. For this purpose the dried powder was treated with $1.0 \%$ w/v NaOH for $2 \mathrm{~h}$, washed with distilled water for several times, and allowed to air dry to use as a medium component (Gharpuray et al., 1983).

\section{Media optimization for pectinase production}

The impacts of 10 independent variables on enzyme activity were tested using Plackett-Burman Design (Plackett and Burman, 1946). Each variable was tested at two levels: the high level (+) and the low level (-) as shown in Table 1. The factors investigated in the current study included salts $\left(\mathrm{NH}_{4}\right)_{2} \mathrm{SO}_{4}, \mathrm{Na}_{2} \mathrm{HPO}_{4}$ $\mathrm{KH}_{2} \mathrm{PO}_{4}, \mathrm{CaCl}_{2} \cdot 2 \mathrm{H}_{2} \mathrm{O}, \mathrm{MgSO}_{4} .7 \mathrm{H}_{2} \mathrm{O}$, yeast extract, orange peel $\mathrm{pH}$, incubation temperature and incubation period.Total 13 runs have been performed and actual experimental and predicted values of pectinase production have been measured.
Table 1 Variables included in the PBD design

\begin{tabular}{llcc}
\hline \multirow{2}{*}{ ode } & Independent variables & \multicolumn{2}{c}{ Level of variables } \\
\cline { 3 - 4 } & & Low level & High level \\
\hline $\mathbf{A}$ & $\left(\mathrm{NH}_{4}\right)_{2} \mathrm{SO}_{4}(\% \mathrm{w} / \mathrm{v})$ & 0.02 & 2.0 \\
\hline $\mathbf{B}$ & $\mathrm{Na}_{2} \mathrm{HPO}_{4}(\% \mathrm{w} / \mathrm{v})$ & 0.06 & 6.0 \\
\hline $\mathbf{C}$ & $\mathrm{KH}_{2} \mathrm{PO}_{4}(\% \mathrm{w} / \mathrm{v})$ & 0.03 & 3.0 \\
\hline $\mathbf{D}$ & $\mathrm{MgSO}_{4} .7 \mathrm{H}_{2} \mathrm{O}(\% \mathrm{w} / \mathrm{v})$ & 0.01 & 1.0 \\
\hline $\mathbf{F}$ & Yeast extract $(\% \mathrm{w} / \mathrm{v})$ & 0.01 & 1.0 \\
\hline $\mathbf{G}$ & Orange peel $(\% \mathrm{w} / \mathrm{v})$ & 0.5 & 5.0 \\
\hline $\mathbf{H}$ & $\mathrm{pH}$ & 7.0 & 9.0 \\
\hline $\mathbf{J}$ & Incubation temperature $\left({ }^{\circ} \mathrm{C}\right)$ & 50 & 37 \\
\hline $\mathbf{K}$ & Incubation Period $(\mathrm{h})$ & 24 & 72 \\
\hline
\end{tabular}

RSM using BBD was applied for optimization of pectinase production that includes full factorial experiment and observation of simultaneous, systematic and efficient variation of significant components on the fermentation process. Three important parameters namely Orange peel concentration (X1), incubation temperature (X2) and initial $\mathrm{pH}(\mathrm{X} 3)$ were selected as the independent variables based on the significant model terms obtained by ANOVA analysis of PB Design and the pectinase activity $\left(\mathrm{IU} . \mathrm{mL}^{-1}\right)$ was the dependent response variable. Each of these independent variables was studied at three different levels as per BBD with a total of 15 experimental runs using statistical software package Design Expert 9.0.5, Stat-Ease, Inc., USA. Pectinase activity (IU. $\mathrm{mL}^{-1}$ ) corresponding to the combined effects of three variables was studied in their specified ranges as shown in Table 2. All the flasks were analyzed for pectinase activity. Threedimensional curves were generated with the same software.

Table 2 Experimental range and coded levels of process variables for pectinase production

\begin{tabular}{llccc}
\hline \multirow{2}{*}{$\begin{array}{l}\text { Coded } \\
\text { value }\end{array}$} & Significant process variables & \multicolumn{3}{c}{$\begin{array}{c}\text { Range and level of } \\
\text { variables }\end{array}$} \\
\cline { 3 - 5 } & & -1 & 0 & +1 \\
\hline $\mathbf{X 1}$ & Orange peel $(\% \mathrm{w} / \mathrm{v})$ & 2.5 & 3.5 & 5.0 \\
\hline $\mathbf{X 2}$ & Incubation temperature $\left({ }^{\circ} \mathrm{C}\right)$ & 35 & 40 & 45 \\
\hline $\mathbf{X 3}$ & $\mathrm{pH}$ & 8.0 & 8.5 & 9.0 \\
\hline
\end{tabular}

For statistical calculations the independent variables were coded as:

$\mathrm{xi}=(\mathrm{Xi}-\mathrm{X} 0) / \delta \mathrm{Xi}$

Where $\mathrm{Xi}$ is the experimental value of the variable; $\mathrm{X} 0$ is the mid-point of $\mathrm{Xi},{ }^{8} \mathrm{Xi}$ is the step change in $\mathrm{Xi}$ and $\mathrm{xi}$ is the coded value for $\mathrm{Xi}, \mathrm{i}=1-3$.

This response surface methodology allows the modeling of a second order equation that describes the process. Pectinase production data was analyzed and response surface model given by Eq. (2) was fitted with multiple regressions through the least squares method.

$\mathrm{Y}=\beta_{0}+\sum \beta_{\mathrm{i}} \mathrm{x}_{\mathrm{i}}+\sum \beta_{\mathrm{ii}} \mathrm{x}_{\mathrm{i}}^{2}+\sum \beta_{\mathrm{ij}} \mathrm{x}_{\mathrm{i}} \mathrm{x}_{\mathrm{i}}$

where $\beta_{0}, \beta_{\mathrm{i}}, \beta_{\mathrm{i} i}$, and $\beta_{\mathrm{ij}}$ represents, respectively the constant process effect, the linear effect of $\mathrm{Xi}$, quadratic effect of $\mathrm{Xi}$ and the interaction effect between $\mathrm{X}$ and $\mathrm{Xj}$ on pectinase activity denoted by $\mathrm{Y}($ Chapla et al., 2010).

\section{Enzyme characterization}

The reaction mixture containing $0.4 \mathrm{~mL}$ of $0.1 \%$ polygalacturonic acid prepared in $0.1 \mathrm{M}$ Glycine- $\mathrm{NaOH}$ buffer $(\mathrm{pH} 8.5)$ and $0.1 \mathrm{~mL}$ of appropriately diluted enzyme was incubated at $40,50,60,70$ and $80^{\circ} \mathrm{C}$ temperatures for $10 \mathrm{~min}$ for pectinase assay to determine the optimum temperature of the reaction. The $\mathrm{pH}$ optima of pectinase at $40^{\circ} \mathrm{C}$ temperature was determined by measuring activity at various $\mathrm{pH}$ values using different buffers, such as sodium citrate $(\mathrm{pH} 5.5)$, sodium phosphate $(\mathrm{pH} 6.0,6.5,7.0,7.5,8.0)$, and glycine- $\mathrm{NaOH}(\mathrm{pH} 8.5,9.0$, 9.5) each at $50 \mathrm{mM}$ concentration under standard assay conditions using polygalacturonic acid as substrate.

Rate of polygalacturonic acid hydrolysis was determined, after incubating substrate at various concentrations at optimized conditions, by measuring the enzyme activity at different substrate concentration. The substrate concentration ranged from 2.5 to $25 \mathrm{mg} \cdot \mathrm{mL}^{-1}$. Rate of the reaction was calculated using absorbance at $550 \mathrm{~nm}$. Graph of substrate concentration against reaction rate was 
plotted. Kinetic parameters such as $\mathrm{Km}$ and Vmax were calculated from the Lineweaver-Burk plot.

Effect of various metal salts viz. $\mathrm{AgNO}_{3}, \mathrm{CaCl}_{2}, \mathrm{CoCl}_{2}, \mathrm{CuCl}_{2}, \mathrm{FeCl}_{3}, \mathrm{HgCl}_{2}$, $\mathrm{KCl}, \mathrm{MgCl}_{2}, \mathrm{MnCl}_{2}, \mathrm{NaCl}, \mathrm{NiCl}_{2}$ and $\mathrm{ZnCl}_{2}$ at a final concentration of $1 \mathrm{mM}$ for 5 min was determined under standard assay condition. Thermostability of the pectinase was determined by preincubating the enzyme at $35,45,50,60,70$ and $80^{\circ} \mathrm{C}$ temperature up to 90 mins. After each interval of $30 \mathrm{~min}$, the enzyme was withdrawn and residual enzyme activity was determined by standard assay procedure.Likewise, the $\mathrm{pH}$ stability of pectinase was ascertained by preincubating the enzyme in buffers of different $6.0,6.5,7.0,7.5,8.0,8.5,9.0$, 9.5 and $10.0 \mathrm{pH}$. After 30 and $60 \mathrm{~min}$ time interval, the enzyme was withdrawn and residual enzyme activity was determined by standard assay procedure.

\section{Pulp sample}

Unbleached Kraft pulp used for the present study was a mixture of 82 to $84 \%$ mixed hardwood and 16 to $18 \%$ bamboo pulp provided by Central Pulp and Paper Research Institute, Saharanpur, U. P., India. The chemical composition of the pulp used was cellulose 75 to $76 \%$, hemicellulose 19 to $20 \%$, lignin 3 to $5 \%$ and pectin $0.1 \%$.

\section{Enzymatic pretreatment of Kraft pulp $\left(\mathbf{E}_{0}\right)$}

One variable at a time approach (OVAT) was taken to establish the best reaction conditions. Unbleached hardwood pulp was pretreated with the pectinoxylanolytic preparation as per standard laboratory manual of testing procedure of Central Pulp and Paper Research Institute (CPPRI), Saharanpur, U.P. India. Pretreatment of pulp with pectino-xylanolytic enzymes was carried out with different enzyme dosage at $50{ }^{\circ} \mathrm{C}$ temperature and $\mathrm{pH} 8.0$ for a retention time of $120 \mathrm{~min}$ based on preliminary studies (Table 3). Shredded, screened an unbleached pulp comparable to $100 \mathrm{OD}$ (oven dried) was taken and divided into two parts. One part was kept as control and the second part was treated with a pectino-xylanolytic preparation of crude enzyme in the ratio of pectinase and xylanase of $5.5: 1$ by adding $5.15 \mathrm{~mL}$ and $7.73 \mathrm{~mL}$ per gram of OD pulp in setand set-II respectively, while maintaining the pulp consistency at $10 \%$. The pulp was thoroughly mixed with enzyme preparation by kneading mechanism and transferred in polyethylene bags to put in a water bath. Control samples were subjected to the same treatment conditions except the enzyme.

Table 3 Pectino-xylanolytic Enzyme Treatment of unbleached pulp (P-stage)

\begin{tabular}{|c|c|c|c|}
\hline Particulars & Control & $\begin{array}{r}\text { Enzyn } \\
\end{array}$ & eated \\
\hline Enzyme dose, IU.gm ${ }^{-1}$ & - & 'Set-I & ${ }^{\#}$ Set-II \\
\hline Consistency (\%) & 10 & 10 & 10 \\
\hline Temperature $\left({ }^{\circ} \mathrm{C}\right)$ & 50 & 50 & 50 \\
\hline $\mathrm{pH}$ & 8.0 & 8.0 & 8.0 \\
\hline Treatment Time (min) & 120 & 120 & 120 \\
\hline
\end{tabular}

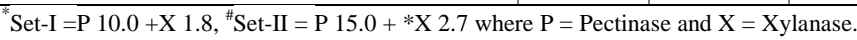

\section{Bleaching of Pulp $\left(D_{0}-E_{p}-D_{1}\right)$}

The enzyme pretreated pulp was subjected to chemical bleaching through a) $\mathrm{D}_{0^{-}}$ stage (chlorine dioxide treatment - CD), b) $\mathrm{E}_{\mathrm{p}}$-stage (alkali treatment) and c) $\mathrm{D}_{1}$ stage. Chlorine dioxide dosage was ascertained by estimation of Kappa No. of unbleached pulp. Pulp Bleaching process conditions are briefly summarized in the table 4.

Table 4 Pulp bleaching process conditions

\begin{tabular}{lccc}
\hline Parameter/stage & $\mathbf{D}_{\mathbf{0}}$ & $\mathbf{E}_{\mathbf{p}}$ & $\mathbf{D}_{\mathbf{1}}$ \\
\hline Consistency $(\%)$ & $10 \%$ & $10 \%$ & $10 \%$ \\
\hline Temperature $\left({ }^{\circ} \mathrm{C}\right)$ & 55 & 70 & 80 \\
\hline $\mathrm{pH}$ & $2-3$ & $>11$ & $3-4$ \\
\hline Retention time (min) & 45 & 60 & 180 \\
\hline
\end{tabular}

\section{a) $D_{0}$-stage (chlorine dioxide stage)}

In this stage, control pulp was mixed with $6.47 \% \mathrm{ClO}_{2}$ while the enzyme treated pulp was distributedinto two parts. One part was treated with the same dose of $\mathrm{ClO}_{2}(6.47 \%)$ whereas the other part was treated with a lesser dose of $\mathrm{ClO}_{2}$ $(5.50 \%)$. All the three pulp samples (control, same and less dose) were put in the polyethylene bags and placed in the water bath.

\section{b) $\mathbf{E}_{\mathrm{p}}$-stage (alkali extraction stage)}

The control and the pulp samples treated with higher and lesser dose of $\mathrm{ClO}_{2}$ were treated with $2.5 \%$ of $\mathrm{NaOH}$ and $1.0 \%$ of $\mathrm{H}_{2} \mathrm{O}_{2}$ in different polyethylene bags and put in a water bath. After that, the pulp was washed similarly as done at the end of P-Stage and pulp pad was prepared.

\section{c) $D_{1}$-stage (dioxide Stage)}

The alkali extracted pulp was treated with Chlorine dioxide in the same way as mentioned in $\mathrm{D}_{0}$-Stage. Subsequently the pulp was washed as done after Pretreatment Stage and pulp pad was prepared and tested for kappa number, brightness, whiteness and yellowness as per TAPPI (Technical Association of the Pulp and Paper Industry, Atlanta) protocols.

\section{Analysis of the pulp-free filtrate}

Miller's method (1959) and procedure given in Laboratory Manual of Testing Procedure, CPPRI, Saharanpur, U.P. were followed to determine the Total Reducing Sugar (TRS), colour $\left(\mathrm{A}_{456}\right)$, lignin $\left(\mathrm{A}_{280}\right)$ and phenolics $\left(\mathrm{A}_{237}\right)$ of pulp filtrates.Lignin content of the effluents was measured by $\mathrm{A}_{280}$. Samples were diluted if required to acquire the absorbance values within of the range 0.2-0.8 Lignin was calculated using the formula, lignin, $m g \cdot \mathrm{mL}^{-1}=\mathrm{A}_{280} \mathrm{x}$ dilution factor/absorptivity of lignin, where the value 21 is used for hardwood and 20 for agro-based lignin.

\section{Analysis of pulp and paper properties}

The enzyme treated pulp was carefully washed and hand sheets were prepared under standardized pressure and air-dried in a room with standardized light, humidity and temperature. The investigation of pulp properties was performed according to TAPPI standard methods. Kappa number, the measure of degree of lignin content of pulp, is estimated by the reaction of pulp samples with acidified potassium permanganate to measure the lignin content (TM I-D1)/TAPPI method T236 cm-85). The brightness of the hand sheets was measured as \% ISO (International Organization for Standardization, ISO) by reflectance at $457 \mathrm{~nm}$ with ISO Colourtech, USA, according to TAPPI protocol (T-452 om-87). The yellowness, whiteness and fluorescence of pretreated pulp were also evaluated by ISO Colourtech, USA at $457 \mathrm{~nm}$ (T 1216).

\section{RESULTS AND DISCUSSION}

Isolation, Screening and Identification of pectinase and xylanase producer strain

In the present study, 24 bacterial isolates were obtained from the soil contaminated with the effluent of an oil refinery, Digboi, Assam, India. Based on the results of the screening a bacterial strain SDB9 which produced maximum pectinase with concurrent production of mediocre levels of xylanase and negligible cellulase activity was selected for further study. The isolate was identified as Bacillus firmus SDB9 based on 16S rRNA gene sequencing. The sequence was submitted to GenBank with the accession number KP881618. The phylogenetic relationship of the isolate SDB9 with other reference taxa is shown in figure 1. The isolate efficiently grew at 30 to $45{ }^{\circ} \mathrm{C}$ temperature with an optimum at $40^{\circ} \mathrm{C}$ (Figure 2a) and optimum $\mathrm{pH}$ for the growth was 8.0. Bacillus firmus reported from the diverse habitats are well-known for the hydrolases producer. Earlier, Bacillus firmus had been reported to be the producer of pectinase and xylanase (El-Shishtawy et al., 2014; Ratanakhanokchai et al. 2002; Roosdiana et al., 2013).

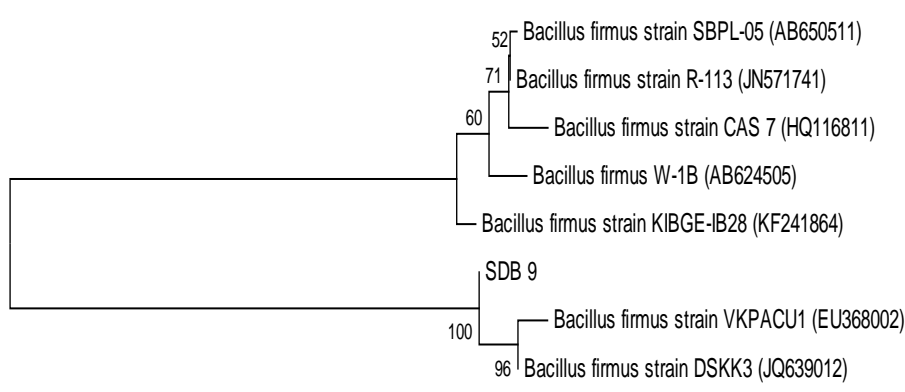

0.1

Figure 1 A phylogenetic tree is showing the taxonomic position of culture SDB9 with the GenBank accession numbers in parenthesis. Only bootstrap values greater than N50\% are shown at nodes (based on 500 bootstrap resampling).

\section{Concurrent production of enzymes and growth profile}

The time course of pectinase production by the isolate was monitored during shake flask fermentation with pectin as a sole source of carbon. Optical density readings at $600 \mathrm{~nm}$ indicated an active $\log$ phase during 6 to $24 \mathrm{~h}$ of fermentation. Highest pectinase activity was found $1.94 \mathrm{IU} \cdot \mathrm{mL}^{-1}$ during the early stationary 
phase at $48 \mathrm{~h}$. The Xylanase activity topped to $0.34 \mathrm{IU}_{\mathrm{mL}} \mathrm{m}^{-1}$ at $48 \mathrm{~h}$ of fermentation with as negligible as $0.086 \mathrm{IU}_{\mathrm{mL}} \mathrm{m}^{-1}$ cellulase activity at $54 \mathrm{~h}$ (Figure 2b). Early production of pectinase was found within $48 \mathrm{~h}$ that is desirable for large scale production.Similar rapid pectinase production was reported in Bacillus licheniformis (Rehman et al., 2012), Bacillus cereus (Sanaa et al. 2014) and even in yeast Saccharomyces cerevisiae (Poondla et al., 2015). The use of concurrently produced pectinase and xylanase from the single organism in the pretreatment of kraft pulp can be economically as well as environmentally friendly (Kaur et al., 2010).

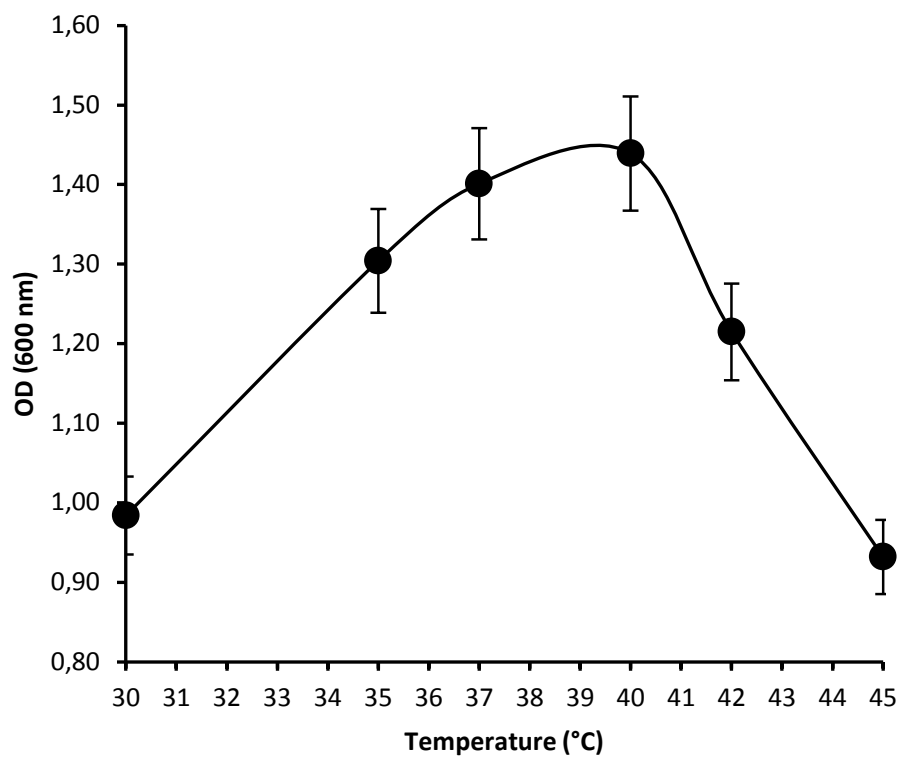

Figure 2a Effect of temperature on growth of isolate SDB9

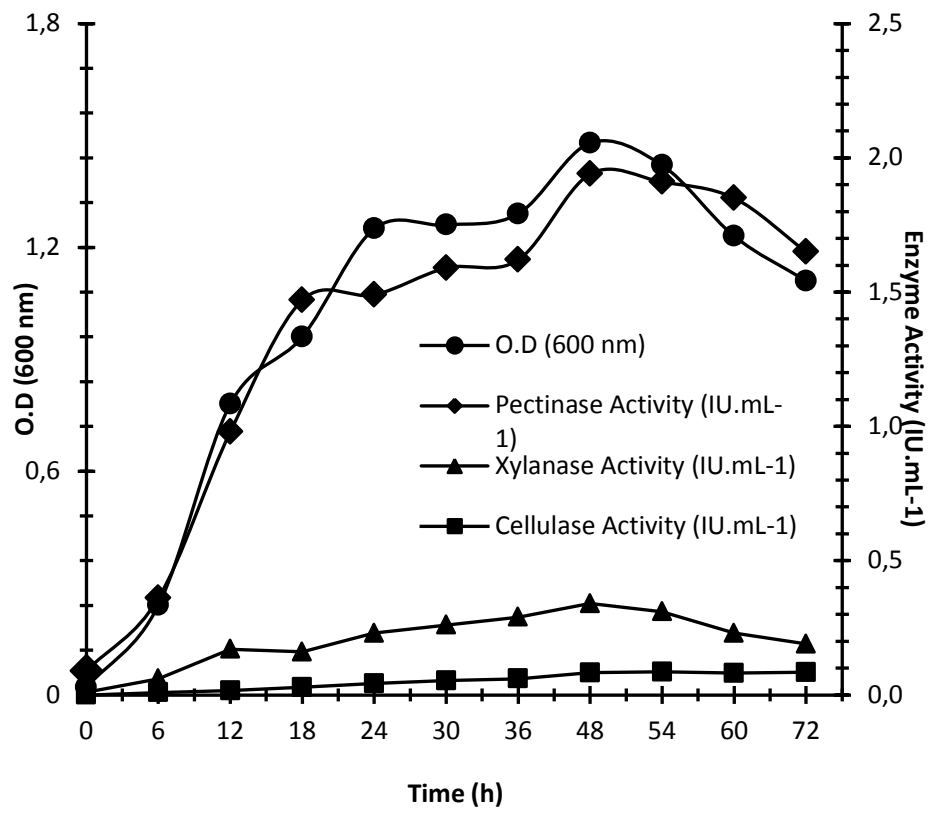

Figure 2b Concurrent production of three enzymes in shake flask condition with growth profile of isolate SDB9

Effect of nitrogen and crude pectin sources on pectinase production

Organic nitrogen sources were superior for the pectinase production than the inorganic nitrogen sources tested in the experiments. A similar pattern is reported in Bacillus licheniformis (Rehman et al., 2012) and Bacillus sp. (Kashyap et al., 2003). Yeast extract was found to be the best source of nitrogen followed by peptone, $\mathrm{NaNO}_{3}, \mathrm{KNO}_{3}, \mathrm{NH}_{4} \mathrm{Cl}$ and Casein (Figure 3). Yeast extract is more preferentially utilized by the Bacillus species for the production of pectinase (Kashyap et al., 2003; Rehman et al., 2012).

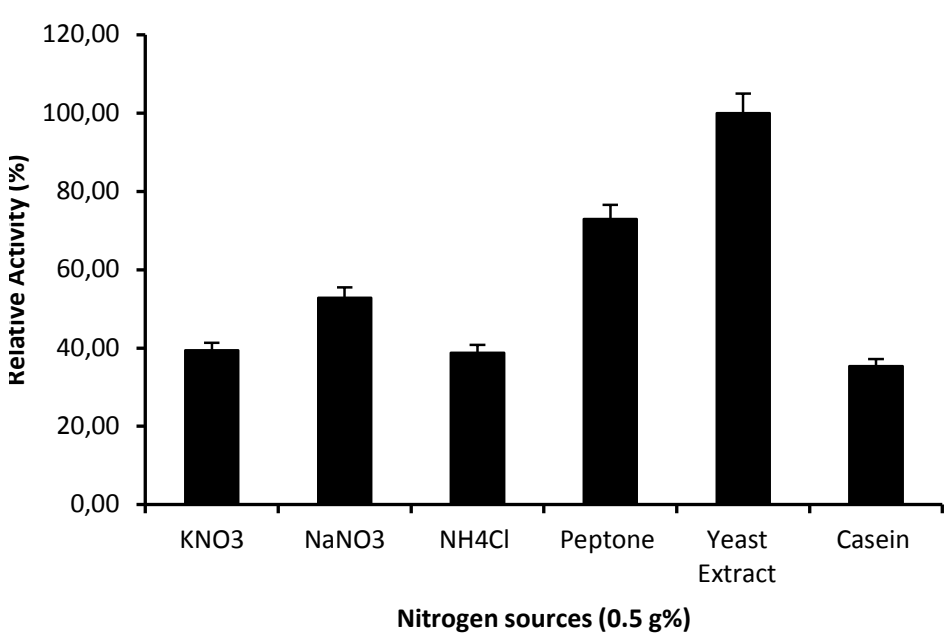

Figure 3 Effect of different Nitrogen sources on pectinase production

The enzyme activity in all the tested crude substrates was found to increase with incubation. On testing different economic waste materials as a substrate for pectinase production, the maximum enzyme output was achieved using an orange peel on $72 \mathrm{~h}$ of fermentation. Earlier, orange peel is reported to be the best source for the pectinase production by Bacillus sp. NTT33 (Cao et al., 2000). Though, the initial phase of $48 \mathrm{~h}$ did not yield highly differential production data However after three days the Orange Peel proved to be a most worthy carbon source for the pectinase production followed by hardwood bark, Banana peel, Jute and pectin (Figure 4). The use of agro-residues for the pectinase production is an alternative biotechnological solution for waste valorization (Martín et al., 2013; Rivas et al., 2008) that is highly acceptable for sustainable development.Among the various agricultural waste including oilseed cake, wheat straw, wheat bran, citrus peel/orange peel were well evaluated as a pectin source for the production of pectinase (Kapoor et al., 2001; Sharma and Satyanarayana, 2012)

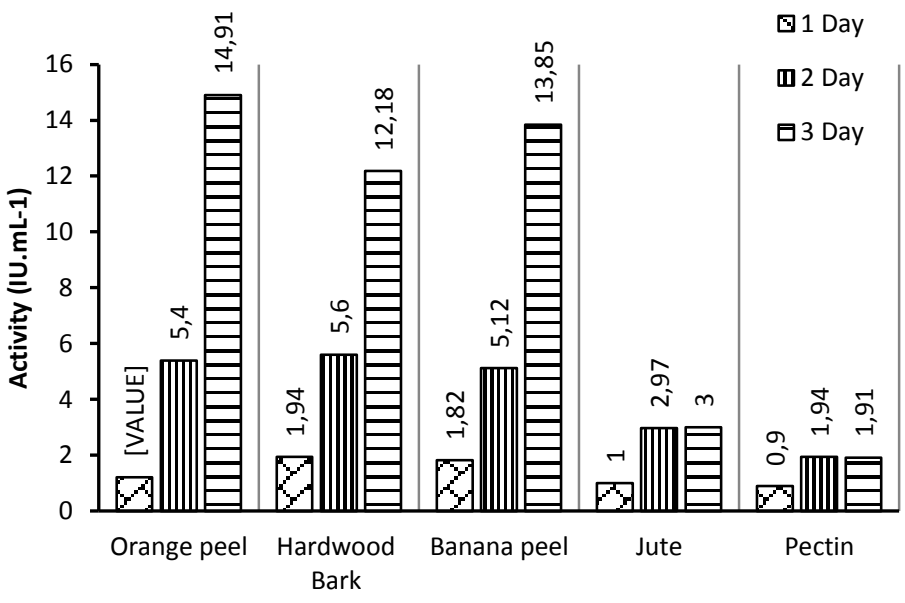

Figure 4 Effect of substrates (Orange peel, Hardwood Bark, Banana peel, Jute and Pectin) on pectinase activity

\section{Media optimization for pectinase production}

Pectinase production by SDB9 with media containing $0.5 \%$ w/v Pectin was successfully attained with supplementation of $0.5 \%$ yeast extract, $0.2 \%$ $\left(\mathrm{NH}_{4}\right)_{2} \mathrm{SO}_{4}, 0.6 \% \mathrm{Na}_{2} \mathrm{HPO} 4,0.3 \% \mathrm{KH}_{2} \mathrm{PO} 4$ and $0.1 \% \mathrm{MgSO}_{4} .7 \mathrm{H}_{2} \mathrm{O}$. However, in optimization studies pectin was replaced with orange peel that principally consists of as much as $25 \%$ to $30 \%$ (dry weight) pectins (Aravantinos-Zafiris $\boldsymbol{e t}$ al., 1994; Ververis et al., 2007) in order to reduce the cost of production.

\section{Plackett-Burman Design (PBD) for screening significant variables}

Manual screening by one variable at-a-time is labor-intensive and timeconsuming. Whereas, PBD decreases the number of experiments needed to effectively achieve experimental goals significantly (Plackett and Burman, 1946). In all, 13 runs were carried out on ten independent variables and one 
dummy variable. The PBD matrix, coded-real values of independent variables studied and the experimental vs. predicted values of pectinase produced are shown in Table 5 .

Higher values of studentized effect, the sum of squares and \% contribution of orange peel, $\mathrm{pH}$ and incubation temperature compared to the rest of the tested variables indicates their pronounced influence on the response (Table 6) Regression analysis and independent variables with significant consequences on pectinase production levels are presented in Table 7. Values of Prob> F less than 0.0500 indicate model terms are significant. In this case, F, G, H are significant model terms. Values greater than 0.1 indicate the model terms are not significant. The Model F-value of 151.69 implies that the model is significant. There is only a $0.01 \%$ chance that an F-value this large could occur due to noise. The "Pred RSquared" of 0.8887 is in reasonable agreement with the "Adj R-Squared" of 0.8981 ; i.e. the difference is less than 0.2 . The adequate precision, the signal to noise ratio of 15.7, suggests an adequate signal. Coefficient Estimate for orange peel, media $\mathrm{pH}$ and incubation temperature turned out to be 5.50, 1.65 and 1.45 The equation in terms of coded factors is pectinase production $=+10.18$ $+5.50 * \mathrm{~F}+1.65 * \mathrm{G}+1.45 * \mathrm{H}$. The combined effect of (i) orange peel and incubation temperature (ii) orange peel and media $\mathrm{pH}$ and (iii) incubation temperature and media $\mathrm{pH}$ on pectinase production are depicted in figure 5 .

Table 5 PBD design to search the independent variables (Compositions) that affects the pectinase production (response)

\begin{tabular}{|c|c|c|c|c|c|c|c|c|c|c|c|c|}
\hline Run & $\begin{array}{c}\mathrm{A}: \\
\left(\mathrm{NH}_{4}\right)_{2} \mathrm{SO}_{4}\end{array}$ & $\begin{array}{c}\text { B: } \\
\mathrm{Na}_{2} \mathrm{PO}_{4}\end{array}$ & $\begin{array}{c}\mathrm{C}: \\
\mathrm{KH}_{2} \mathrm{PO}_{4}\end{array}$ & $\begin{array}{c}\text { D: } \\
\text { MgSO }_{4} \cdot \\
7_{4} \mathbf{O}\end{array}$ & $\begin{array}{c}\text { E: } \\
\text { Yeast } \\
\text { Extract }\end{array}$ & $\begin{array}{c}\text { F: } \\
\text { Orange } \\
\text { Peel }\end{array}$ & $\begin{array}{l}\text { G: } \\
\text { pH }\end{array}$ & $\begin{array}{c}\text { H: } \\
\text { Incubation } \\
\text { Temp. }\end{array}$ & $\begin{array}{c}\mathbf{J}: \\
\begin{array}{c}\text { Incubation } \\
\text { Period }\end{array}\end{array}$ & $\begin{array}{c}\mathrm{K}: \\
\mathrm{CaCl}_{2} \cdot \\
2 \mathrm{H}_{2} \mathrm{O}\end{array}$ & $\begin{array}{c}\text { Experi- } \\
\text { mental } \\
\text { Pectinase } \\
\text { Activity }\end{array}$ & $\begin{array}{c}\text { Predicted } \\
\text { Pectinase } \\
\text { Activity }\end{array}$ \\
\hline & $\% \mathrm{w} / \mathrm{v}$ & $\% \mathrm{w} / \mathrm{v}$ & $\% \mathrm{w} / \mathrm{v}$ & $\% \mathrm{w} / \mathrm{v}$ & $\% \mathrm{w} / \mathrm{v}$ & $\% \mathrm{w} / \mathrm{v}$ & & ${ }^{\circ} \mathrm{C}$ & $\mathrm{h}$ & $\% \mathrm{w} / \mathrm{v}$ & IU.mL ${ }^{-1}$ & IU.mL $\mathrm{mL}^{-1}$ \\
\hline 1 & 1 & 1 & -1 & 1 & 1 & 1 & -1 & -1 & -1 & 1 & 13.5 & 11.826 \\
\hline 2 & -1 & -1 & 1 & -1 & 1 & 1 & -1 & 1 & 1 & 1 & 14.1 & 14.406 \\
\hline 3 & -1 & -1 & -1 & -1 & -1 & -1 & -1 & -1 & -1 & -1 & 0.92 & 1.163 \\
\hline 4 & 0 & 0 & 0 & 0 & 0 & 0 & 0 & 0 & 0 & 0 & 15.21 & 15.21 \\
\hline 5 & 1 & -1 & -1 & -1 & 1 & -1 & 1 & 1 & -1 & 1 & 8.31 & 7.37 \\
\hline 6 & -1 & -1 & -1 & 1 & -1 & 1 & 1 & -1 & 1 & 1 & 15.1 & 15.453 \\
\hline 7 & 1 & -1 & 1 & 1 & -1 & 1 & 1 & 1 & -1 & -1 & 17.26 & 18.033 \\
\hline 8 & -1 & 1 & 1 & -1 & 1 & 1 & 1 & -1 & -1 & -1 & 15.42 & 15.45 \\
\hline 9 & 1 & -1 & 1 & 1 & 1 & -1 & -1 & -1 & 1 & -1 & 1.1 & 1.163 \\
\hline 10 & -1 & 1 & -1 & 1 & 1 & -1 & 1 & 1 & 1 & -1 & 8.57 & 7.37 \\
\hline 11 & 1 & 1 & -1 & -1 & -1 & 1 & -1 & 1 & 1 & -1 & 14.2 & 14.4 \\
\hline 12 & 1 & 1 & 1 & -1 & -1 & -1 & 1 & -1 & 1 & 1 & 3.81 & 4.79 \\
\hline 13 & -1 & 1 & 1 & 1 & -1 & -1 & -1 & 1 & -1 & 1 & 2.89 & 3.743 \\
\hline
\end{tabular}

Table 6 Proportionate effects on independent variables on response (Pectinase production)

\begin{tabular}{|c|c|c|c|}
\hline Intercept & $\begin{array}{c}\text { Studentized } \\
\text { Effect }\end{array}$ & $\begin{array}{c}\text { Sum of } \\
\text { Squares }\end{array}$ & $\begin{array}{c}\% \\
\text { Contribution } \\
\end{array}$ \\
\hline $\mathrm{A}-\left(\mathrm{NH}_{4}\right)_{2} \mathrm{SO}_{4}$ & 0.14 & 0.062 & 0.014 \\
\hline $\mathrm{B}-\mathrm{Na}_{2} \mathrm{PO}_{4}$ & 0.21 & 0.14 & 0.030 \\
\hline $\mathrm{C}-\mathrm{KH}_{2} \mathrm{PO}_{4}$ & -0.95 & 2.71 & 0.59 \\
\hline $\mathrm{D}-\mathrm{MgSO}_{4} \cdot 7 \mathrm{H}_{2} \mathrm{O}$ & -0.050 & 7.500E-003 & $1.648 \mathrm{E}-003$ \\
\hline E-Yeast Extract & 1.19 & 4.25 & 0.93 \\
\hline F-Orange Peel & 10.99 & 362.34 & 79.61 \\
\hline G-pH & 3.30 & 32.67 & 7.18 \\
\hline H-Incubation Temp. & 2.91 & 25.35 & 5.57 \\
\hline J-Incubation Period & 0.090 & 0.024 & 5.339E-003 \\
\hline $\mathrm{K}-\mathrm{CaCl}_{2}$ & 0.093 & 0.026 & 5.742E-003 \\
\hline
\end{tabular}

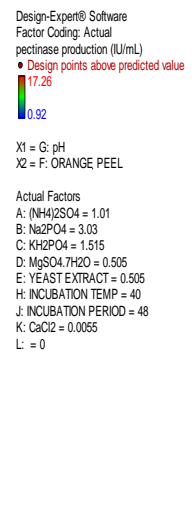

Table 7 Regression analysis of PBDesign

\begin{tabular}{llll}
\hline Source & $\begin{array}{l}\text { Regression } \\
\text { Coefficient } \\
\text { Estimate }\end{array}$ & $\begin{array}{l}\text { Sum of } \\
\text { Squares }\end{array}$ & Df \\
\hline Model & & 420.36 & 3 \\
\hline F-Orange Peel & 5.50 & 362.34 & 1 \\
\hline G-pH & 1.65 & 32.67 & 1 \\
\hline H-Incubation Temperature & 1.45 & 25.35 & 1 \\
\hline Curvature & - & 27.40 & 1 \\
\hline Residual & - & 7.39 & 8 \\
\hline Cor Total & - & 455.15 & 12 \\
\hline
\end{tabular}

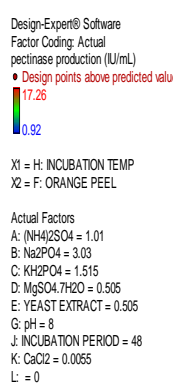

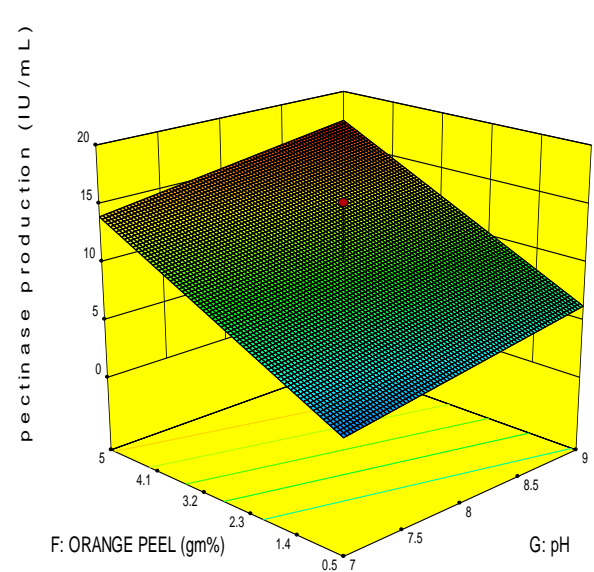

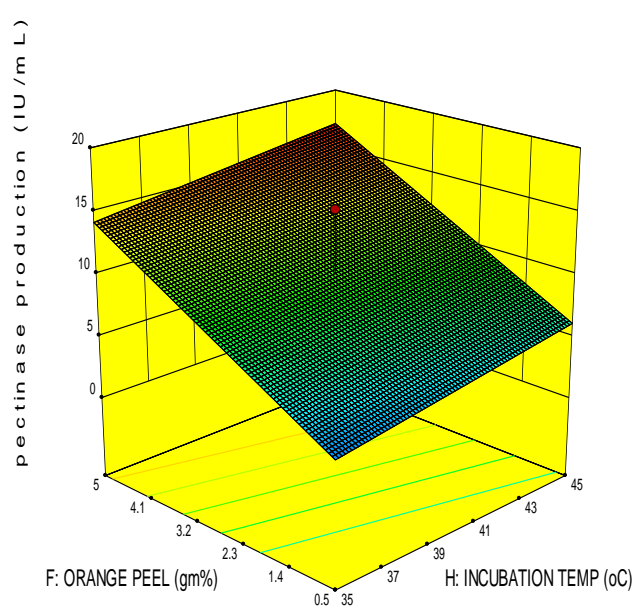




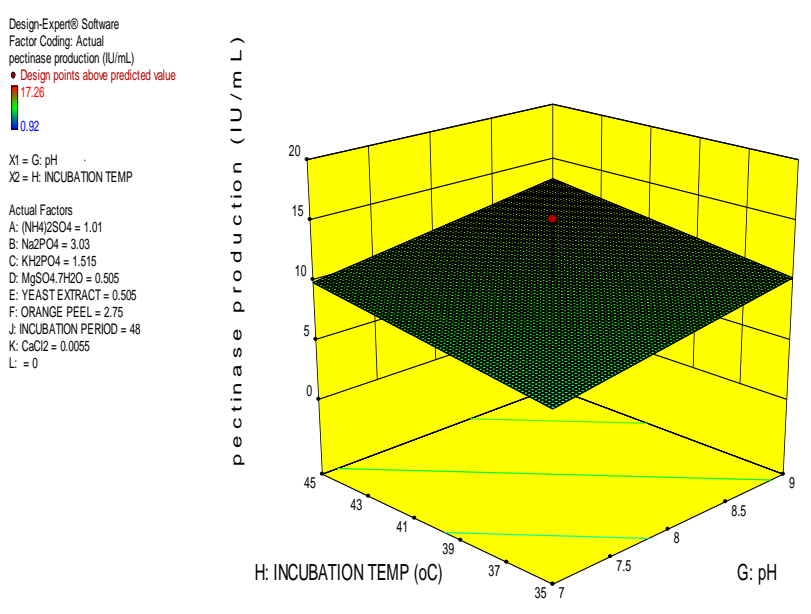

(iii)

Figure 5 The combined effect of (i) orange peel and incubation temperature (ii) orange peel and media $\mathrm{pH}$ and (iii) incubation temperature and media $\mathrm{pH}$ on the response (Pectinase production)

\section{Response surface methodology for optimization of pectinase production using Box-Behnken design}

Three important parameters namely Orange peel concentration (X1), incubation temperature (X2) and initial $\mathrm{pH}$ of media (X3) were selected as the independent variables based on PBDesign to determine the optimal values. The plan of BBD in the coded levels of the three independent variables and the obtained results are shown in Table 8 . The enzyme activity (Pectinase $\mathrm{IU} \cdot \mathrm{mL}^{-1}$ ) was the only dependent response variable tested.

Table 8 Box-Benkhen Design with coded levels of three independent process variables and experimental vs. predicted pectinase activity

\begin{tabular}{lccccc}
\hline Run & $\begin{array}{c}\text { Orange } \\
\text { Peel } \\
(\mathbf{X} 1)\end{array}$ & $\begin{array}{c}\text { Temperature } \\
\text { (X2) }\end{array}$ & $\begin{array}{c}\text { pH } \\
(\mathbf{X 3 )}\end{array}$ & $\begin{array}{c}\text { Experimental } \\
\text { Pectinase } \\
\text { Activity } \\
\text { (IU.mL }^{-1} \text { ) }\end{array}$ & $\begin{array}{c}\text { Predicted } \\
\text { Pectinase } \\
\text { Activity } \\
\text { (IU.mL }^{-1} \text { ) }\end{array}$ \\
\hline $\mathbf{1}$ & 0 & -1 & 1 & 10.89 & 10.85 \\
\hline $\mathbf{2}$ & -1 & 0 & -1 & 16.55 & 16.49 \\
\hline $\mathbf{3}$ & 0 & 1 & -1 & 14.69 & 14.761 \\
\hline $\mathbf{4}$ & 1 & 0 & -1 & 17.55 & 17.587 \\
\hline $\mathbf{5}$ & 0 & 0 & 0 & 12.87 & 13.17 \\
\hline $\mathbf{6}$ & 0 & 0 & 0 & 13.23 & 13.17 \\
\hline $\mathbf{7}$ & -1 & -1 & 0 & 11.81 & 11.86 \\
\hline $\mathbf{8}$ & -1 & 1 & 0 & 11.37 & 11.36 \\
\hline $\mathbf{9}$ & 0 & -1 & -1 & 14.17 & 14.137 \\
\hline $\mathbf{1 0}$ & 0 & 0 & 0 & 13.41 & 13.16 \\
\hline $\mathbf{1 1}$ & 1 & 1 & 0 & 12.51 & 12.45 \\
\hline $\mathbf{1 2}$ & -1 & 0 & 1 & 11.01 & 11.0 \\
\hline $\mathbf{1 3}$ & 1 & 0 & 1 & 12.21 & 12.24 \\
\hline $\mathbf{1 4}$ & 0 & 1 & 1 & 10.05 & 10.06 \\
\hline $\mathbf{1 5}$ & 1 & -1 & 0 & 12.59 & 12.6 \\
\hline
\end{tabular}

ANOVA (analysis of variance) was employed for the determination of significant effects of variables for pectinase production. The detected Pectinase production ranged between 10.85 to $17.58 \mathrm{IU} . \mathrm{mL}^{-1}$ with the conditions tested. To make the model significant the response transformation from the power family with lambda -1.31 and constant $\mathrm{k}=0$ was applied based on the recommendation of the Box-Cox plot (Table 9).

Table 9 ANOVA for Response Surface Quadratic model

\begin{tabular}{|c|c|c|c|c|c|c|}
\hline Source & SS & Df & MS & $\begin{array}{c}\mathbf{F} \\
\text { Statistics }\end{array}$ & p-value & \\
\hline Model & $6.639 \mathrm{E}-004$ & 9 & 7.377E-005 & 184.65 & $<0.0001$ & Significant \\
\hline A-Orange Peel & $2.957 E-005$ & 1 & $2.957 E-005$ & 74.02 & 0.0004 & \\
\hline B-Temperature & $4.116 E-006$ & 1 & $4.116 E-006$ & 10.30 & 0.0237 & \\
\hline$C-p H$ & $5.115 E-004$ & 1 & $5.115 E-004$ & 1280.28 & $<0.0001$ & \\
\hline$A B$ & $7.266 E-007$ & 1 & $7.266 E-007$ & 1.82 & 0.2353 & \\
\hline$A C$ & $3.239 E-006$ & 1 & $3.239 E-006$ & 8.11 & 0.0359 & \\
\hline$B C$ & $9.884 E-006$ & 1 & $9.884 E-006$ & 24.74 & 0.0042 & \\
\hline$A^{2}$ & $2.479 E-006$ & 1 & $2.479 E-006$ & 6.21 & 0.0551 & \\
\hline$B^{2}$ & $9.381 E-005$ & 1 & $9.381 E-005$ & 234.80 & $<0.0001$ & \\
\hline$C^{2}$ & $3.207 E-006$ & 1 & $3.207 E-006$ & 8.03 & 0.0365 & \\
\hline Residual & $1.998 \mathrm{E}-006$ & 5 & 3.995E-007 & & & \\
\hline Lack of Fit & $2.248 E-007$ & 3 & $7.494 E-008$ & 0.085 & 0.9622 & not significant \\
\hline Pure Error & $1.773 E-006$ & 2 & $8.864 E-007$ & & & \\
\hline Cor Total & $6.659 \mathrm{E}-004$ & 14 & & & & \\
\hline
\end{tabular}

The Model F-value of 184.65 implies the model is significant. There is only a $0.01 \%$ chance that an F-value this large could occur due to noise. In this case, $\mathrm{A}$ $\mathrm{B}, \mathrm{C}, \mathrm{AC}, \mathrm{BC}, \mathrm{B}^{2}, \mathrm{C}^{2}$ are significant factors or interactions. The Lack of Fit $\mathrm{F}$ value of 0.08 suggests that the model is fit. Analysis of variance for pectinase production shows that quadratic model is significant with $\mathrm{F}$ value 184.65 and $\mathrm{p}$ value $<0.0001$ as shown in Table 9. The coefficient of determination $\left(R^{2}\right)$ was calculated to be 0.9970 indicating that the model could explain $99 \%$ of the variability. The coefficients for the linear effect of Orange Peel, Temperature and $\mathrm{pH}$ were highly significant. The interactive effect of Orange Peel and Temperature was less significant than the interactive effect of Orange Peel and $\mathrm{pH} \&$ Temperature and $\mathrm{pH}$. Also, Temperature and $\mathrm{pH}$ were quadratically significant. The fitted Quadratic model for pectinase activity in terms of coded process variables is:

$\mathrm{Y}=($ Enzyme Activity) $-1.31=+0.034-1.923 \mathrm{E}-003 * \mathrm{~A}+7.173 \mathrm{E}-004 * \mathrm{~B}+7.996 \mathrm{E}-$ 003* C-4.262E-004* AB-8.999E-004* AC+1.572E-003* BC-8.194E-004 * $\mathrm{A} 2+5.040 \mathrm{E}-003 * \mathrm{~B} 2-9.319 \mathrm{E}-004 * \mathrm{C} 2$

The "Adeq Precision" value of 48.759 indicates an adequate signal and therefore, the model is significant for the process. The 3D response surfaces with contour were plotted on the basis of the model equation so as to investigate the interaction of the factors and to measure the optimum values of each factor for maximum pectinase production by Bacillus sp. SDB9. The optimum concentration of the respective components is represented by the coordinates of the central point within the highest contour lines in each of the graphics. Contour and 3D plot show the interactions of orange peel and incubation temperature at constant $\mathrm{pH}$ 8.0. Pectinase production increases with increasing orange peel concentration $(2.5 \%, \mathrm{w} / \mathrm{v}$ to $5.0 \%, \mathrm{w} / \mathrm{v})$. The increase in temperature up to $40^{\circ} \mathrm{C}$ enhanced the production then after it declined (Figure 6a and 6b). Furthermore, moderate increase in pectinase production was seen with increasing orange peel concentration $(2.5 \%$, w/v to $5.0 \%, \mathrm{w} / \mathrm{v})$ but the rise in $\mathrm{pH}$ from $\mathrm{pH} 8.0$ adversely influenced the production (Figure $7 \mathrm{a}$ and $7 \mathrm{~b}$ ). Similarly, a modest increase in pectinase production was seen with increasing temperature but the rise in $\mathrm{pH}$ from $\mathrm{pH} 8.0$ reduced the production (Figure $8 \mathrm{a}$ and $8 \mathrm{~b}$ ). 

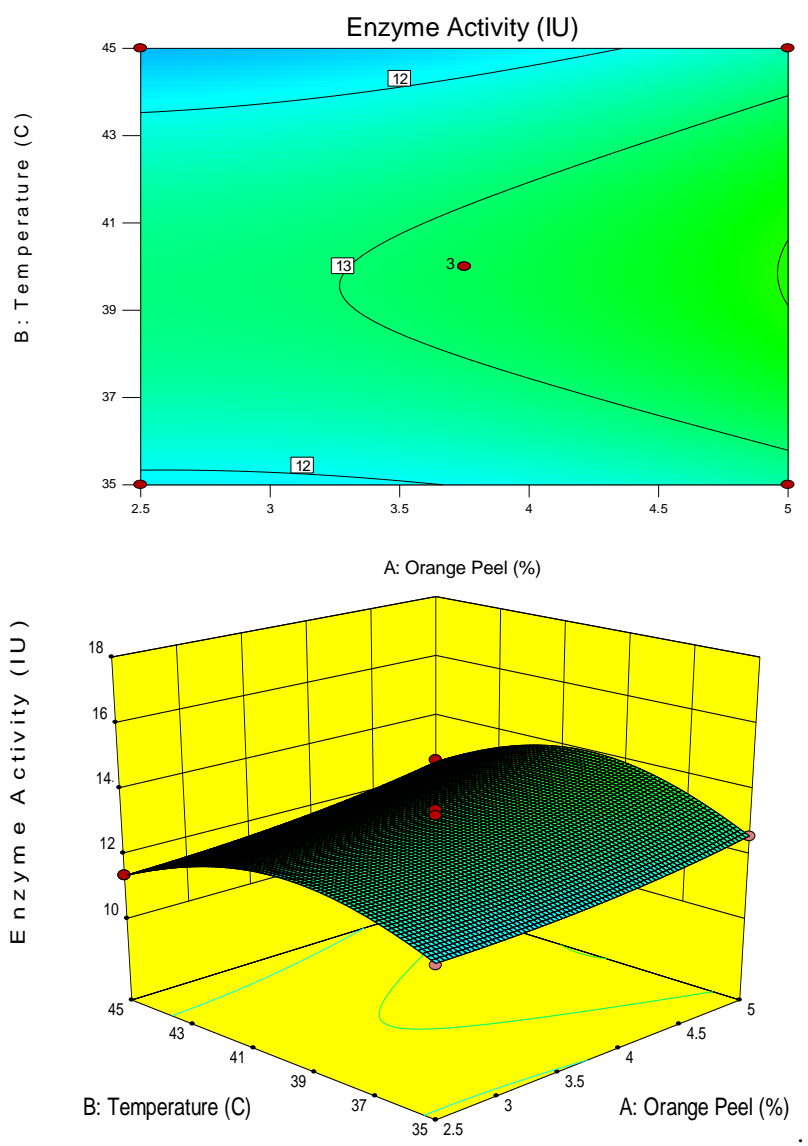

Figure 6 (a) Contour plots and (b) 3D response surface curves shows the interactions of orange peel and incubation temperature on production of pectinase by SDB9 strain at constant $\mathrm{pH} 8.0$
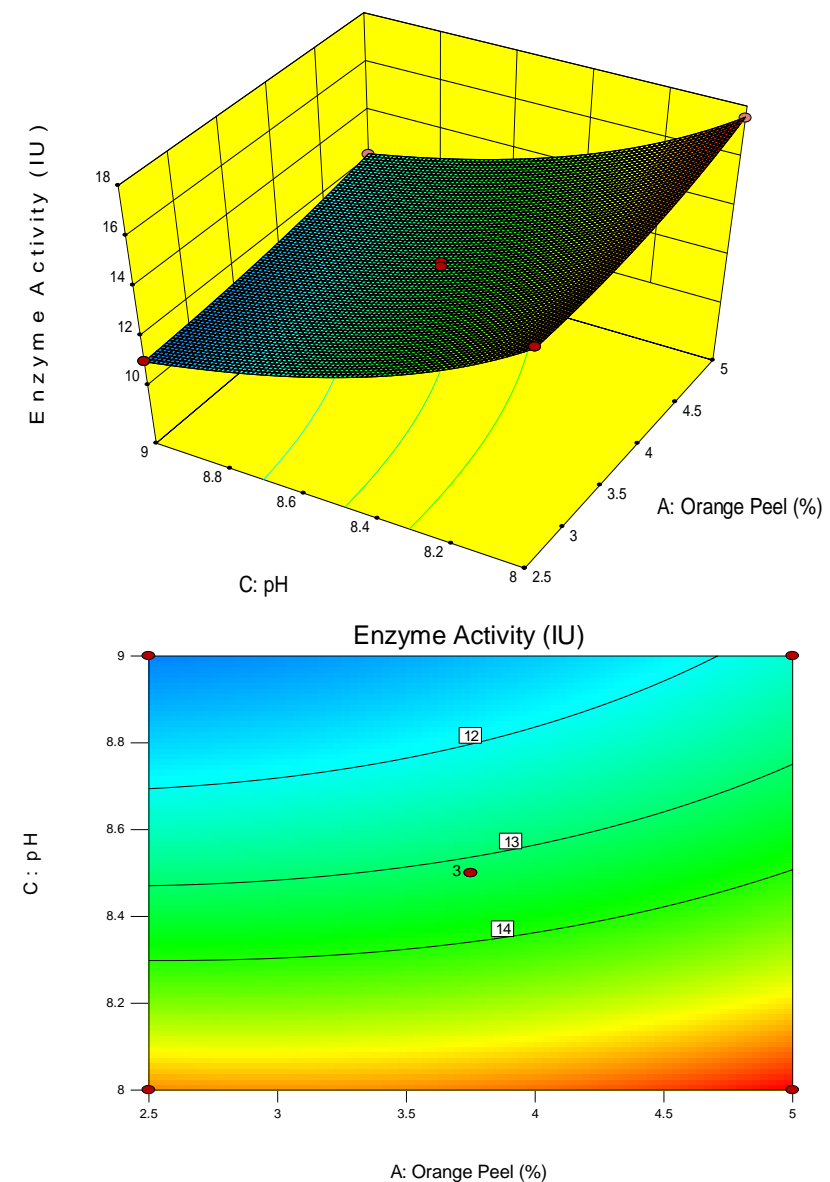

Figure 7(a) Contour plots and (b) 3D response surface curves shows the shows the interactions of orange peel and $\mathrm{pH}$ on production of pectinase at constant temperature $40^{\circ} \mathrm{C}$
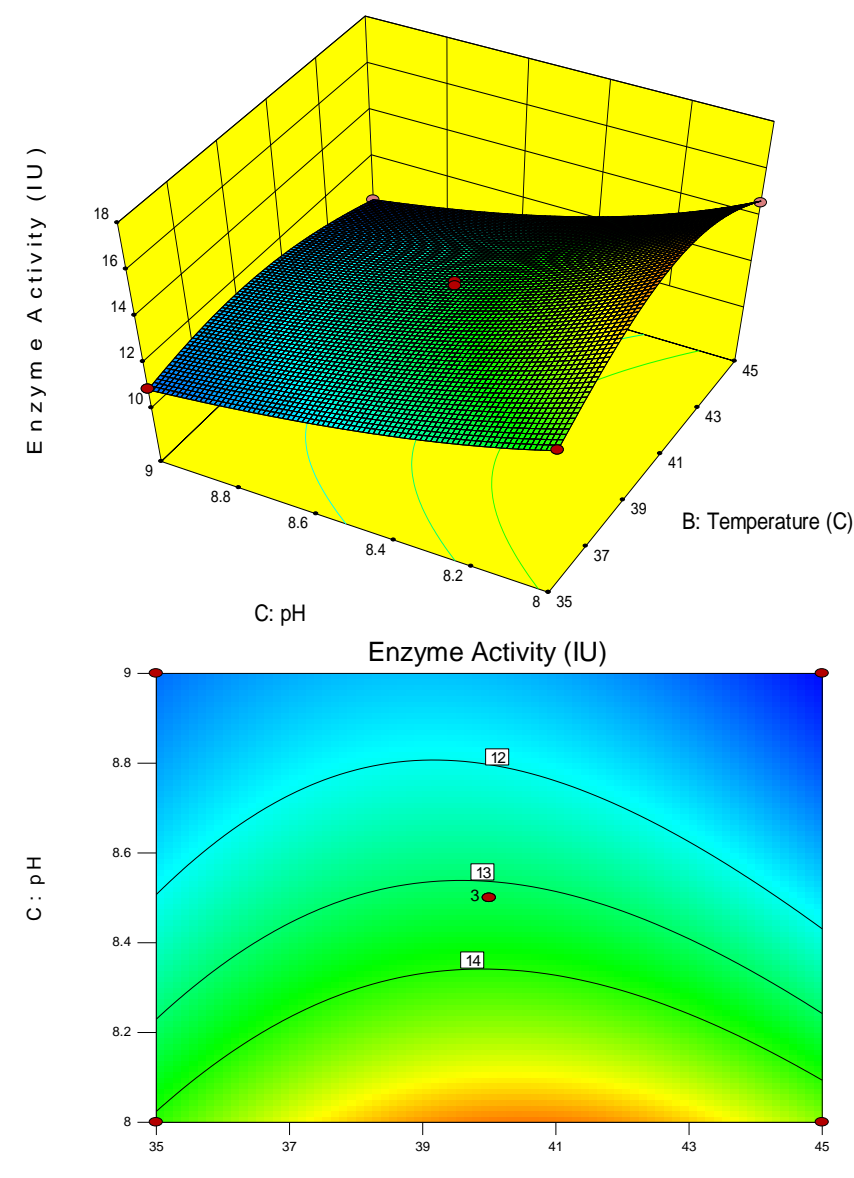

B: Temperature (C)

Figure 8 (a) Contour plots and (b) 3D response surface curves shows the interactions of $\mathrm{pH}$ and temperature on production of pectinase at constant orange peel concentration $(3.75 \% \mathrm{w} / \mathrm{v})$

The maximum predicted pectinase activity was $17.58 \mathrm{IU} \cdot \mathrm{mL}^{-1}$, which was very close to the actual obtained value of $17.55 \mathrm{IU} \cdot \mathrm{mL}^{-1}$ corresponding to increasing levels of orange peel $(5.0 \% \mathrm{w} / \mathrm{v})$, temperature $\left(40^{\circ} \mathrm{C}\right)$ and a lower level $\mathrm{pH}$ (8.0). (Figure 9). The pectinase yield in the optimized medium was $17 \%$ higher than that in the initial medium. The production of pectinase increases with increase in concentration of orange peel, but the incremental production is not proportionate so the lower concentration of $2.5 \%$ of orange peel can be considered for practical application and save on the usage of substrate. Production of pectinase from SDB9 at $72 \mathrm{~h}, 40^{\circ} \mathrm{C}$ and $\mathrm{pH} 8.0$ on $2.5 \% \mathrm{w} / \mathrm{v}$ orange peel as agricultural residue material is recommended to achieve higher yield of $16.49 \mathrm{IU} . \mathrm{mL}^{-1}$. Few recent discrete reports on optimization of pectinase production by Bacillus species using statistical approach are available in scientific literature that includes the screening by PBDesign and subsequent determination of optimal values of significant model terms C:N ratio, $\mathrm{K}_{2} \mathrm{HPO}_{4}$ and $\mathrm{pH}$ (Sharma and Satyanarayana, 2006).The raw substrate and abiotic parameters dominated the outcome of optimization experiments for pectinase production in Bacillus licheniformis SHG10 strains (Embaby et al., 2014). 


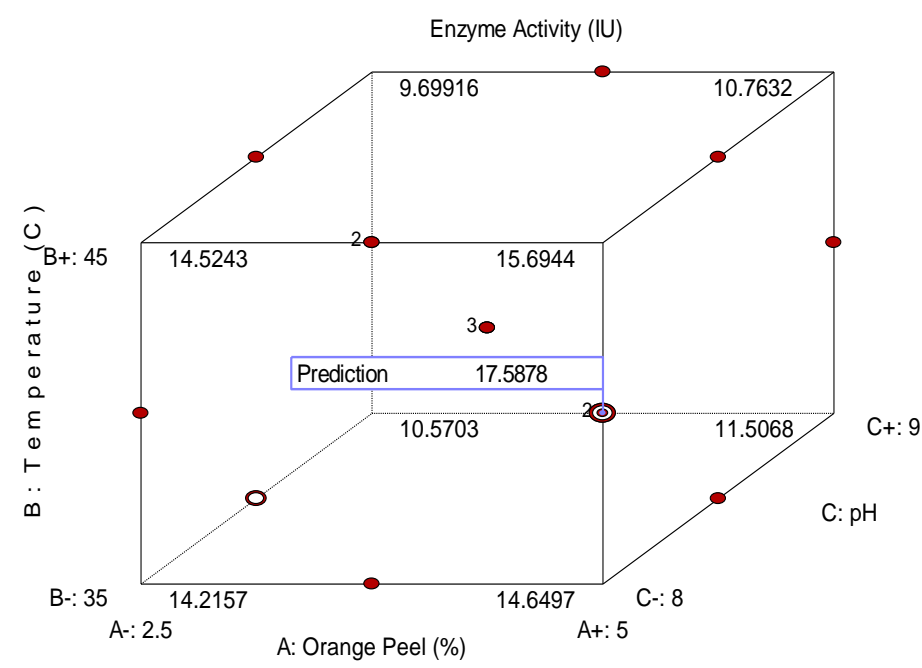

Figure 9 Cube plot showing the influence of factors relevant to the pectinase production A: Orange peel, B: temperature and $\mathrm{C}$ : $\mathrm{pH}$

\section{Enzyme characterization}

For the precipitation of the enzyme $50 \%$ concentration of $\left(\mathrm{NH}_{4}\right)_{2} \mathrm{SO}_{4}$ found to be optimum, followed by dialysis. This partially purified enzyme was used in the characterization

Using different $\mathrm{pH}$ buffers, peak activity of Bacillus sp. SDB9 pectinase was observed with assay buffer at $\mathrm{pH} 8.5$ and more than $50 \%$ activity was retained at pH 7.5 and 9.5 (Figure 10). The optimum temperature for SDB 9 pectinase activity was found to be $45^{\circ} \mathrm{C}$ (Figure 11). The catalytic activity of pectinase was reported in neutral to alkaline $\mathrm{pH}$ with abroad temperature range that is similar to the pectinase of Bacillus pumilus (Sharma and Satyanarayana, 2006). The augmented activity of pectinase in the presence of the divalent cations including $\mathrm{Mg}^{2+}, \mathrm{Ca}^{2+}, \mathrm{Mn}^{2+}$ and $\mathrm{Co}^{2+}$ suggest the metalloprotein nature. However $\mathrm{K}^{+}, \mathrm{Zn}^{2+}$ and $\mathrm{Fe}^{3+}$ cause the drastic inhibition of the enzyme activity (Figure 12). Positive modulatory effect of $\mathrm{Mg}^{2+}$ and $\mathrm{Ca}^{2+}$, on S-I and S-II pectinase of $B$. gibsonii as well as Bacillus sp. KSM-P576 supports our investigation (Kobayashi $\boldsymbol{e}$ t al., 2001; Zu-ming et al., 2008). $\mathrm{Zn}^{2+}$ is a well-reported inhibitor of pectinase (Kusuma and Reddy, 2014; Roosdiana et al., 2013) which in agreement with the present findings.

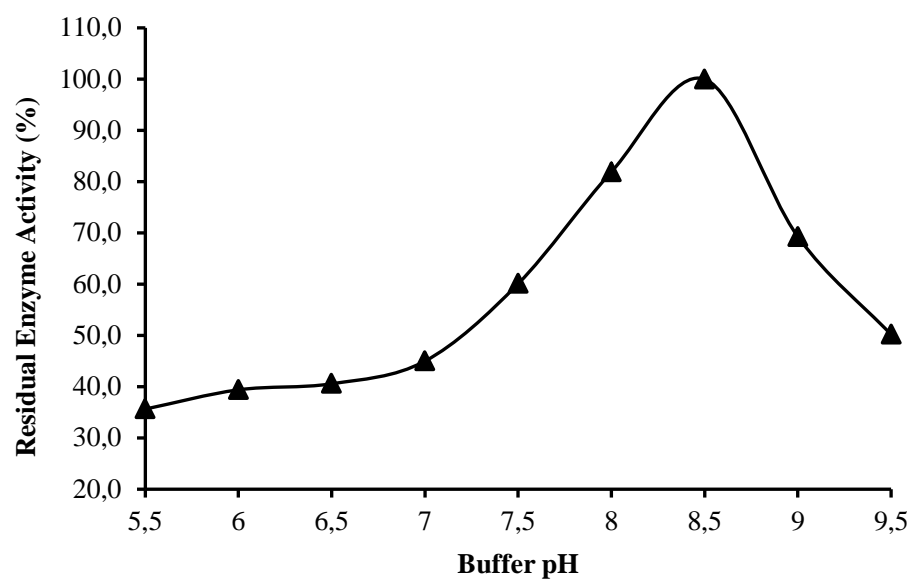

Figure 10 Effect of assay $\mathrm{pH}$ on pectinase activity

The enzyme was found to perform optimally at $45^{\circ} \mathrm{C}$. However, it works on wide range of temperature ranging from 30 to $50^{\circ} \mathrm{C}$. The enzyme was thermo-sensitive beyond $45^{\circ} \mathrm{C}$ as its activity was decreased drastically (Figure 11).

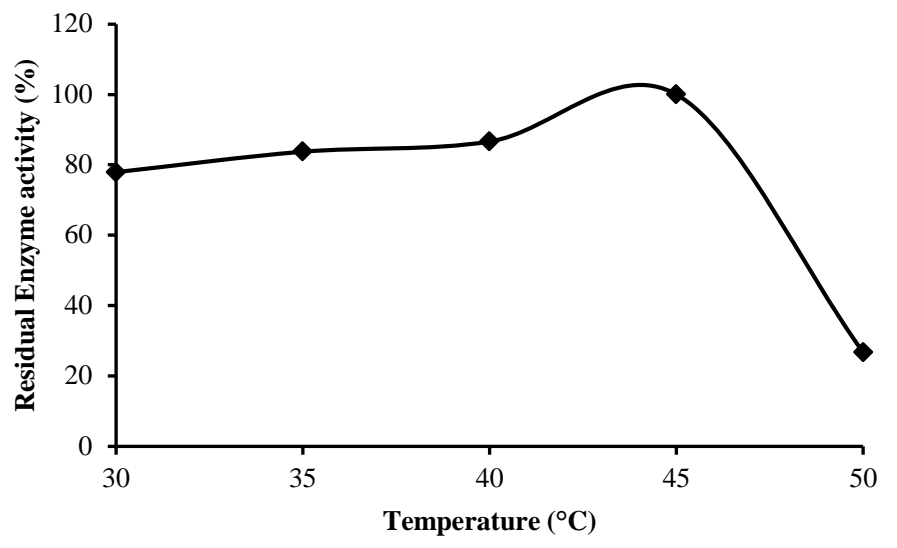

Figure 11 Effect of assay temperature on pectinase activity

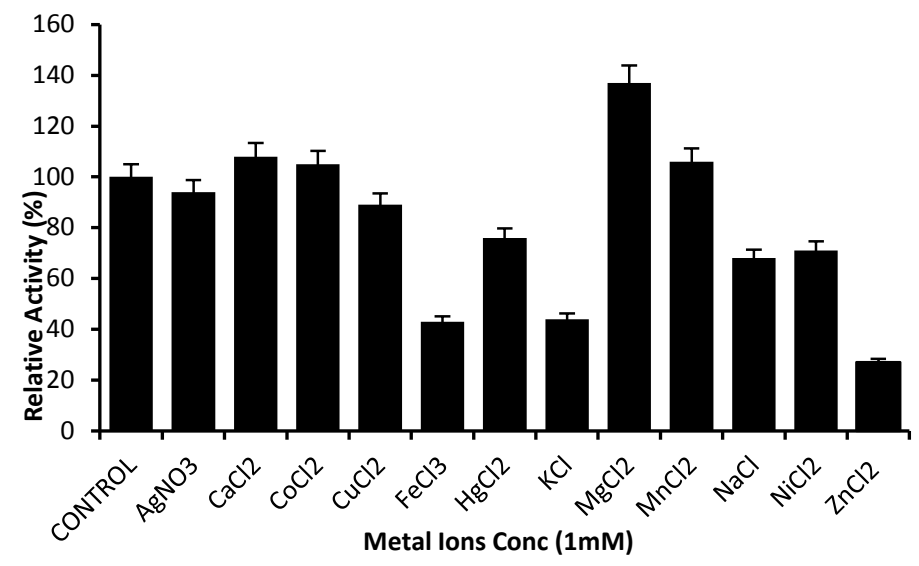

Figure 12 Effect of Metal Ions on SDB9 pectinase activity

The Km and Vmax values of the partially purified pectinase from Bacillus sp. SDB9 were calculated to be $2.090 \mathrm{mg} \cdot \mathrm{mL}^{-1}$ and $1.798 \mathrm{IU} \cdot \mathrm{mL}^{-1}$, respectively (Figure 13). The R-value indicates that almost $98 \%$ of the variation in $\mathrm{v}_{\mathrm{o}}^{-1}(\mathrm{y})$ is due to the variation in $\mathrm{S}^{-1}(\mathrm{x})$. The $\mathrm{Km}$ and Vmax values of the enzyme are harmonious for use at industrial scale.

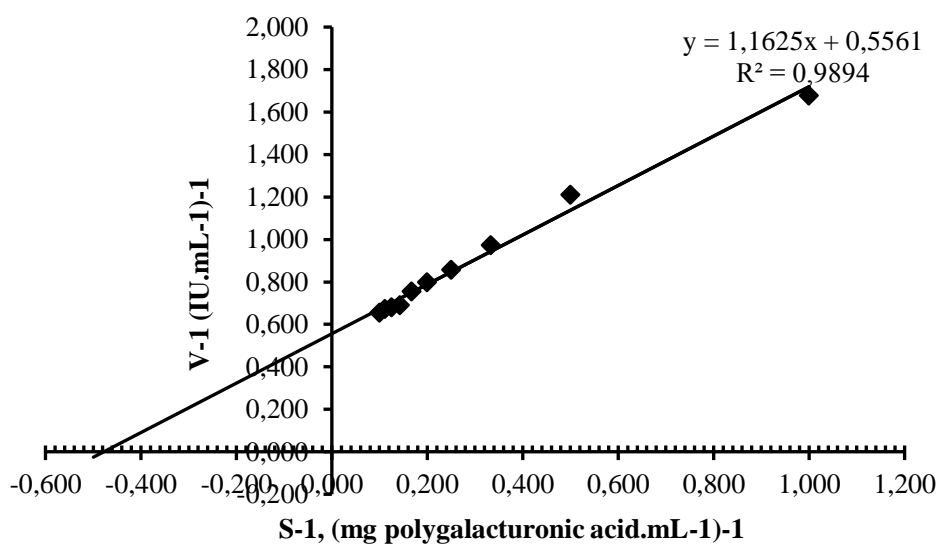

Figure 13 Line Weaver Burk Plot of initial velocity data for pectinase on polygalacturonic acid $\left(2.5\right.$ to $\left.25 \mathrm{mg} \cdot \mathrm{mL}^{-1}\right)$ measured at $45^{\circ} \mathrm{C}$ and $\mathrm{pH} 8.5$

An enzyme was found to remain active at elevated temperature, and thus it was thermostable in nature. The enzyme demonstrated highest stability at $\mathrm{pH} 8.5$. The decline in enzyme stability was drastic beyond $\mathrm{pH} 8.5$ whereas it was gradual below this $\mathrm{pH}$. i.e. Pectinase retained only $48.7 \%$ and $38.2 \%$ activity up to 60 $\min$ at $\mathrm{pH} 7.5$ and 9.5 .Furthermore, pectinase from SDB9 retained $50.17 \%$ relative activity at $\mathrm{pH} 9.5$ (Figure 14). The enzyme showed thermal stability in a broad range of temperatures. The enzyme retained $86 \%$ and $69 \%$ activity at $60^{\circ} \mathrm{C}$ and $70^{\circ} \mathrm{C}$ for $60 \mathrm{~min}$. Nearly, half activity was conserved up to $90 \mathrm{~min}$ at $70^{\circ} \mathrm{C}$ Thus, the enzyme is vastly stable thermally up to temperatures as high as $70^{\circ} \mathrm{C}$ for time up to $90 \mathrm{~min}$. Mere, $12 \%$ activity,was recorded at $80^{\circ} \mathrm{C}$ after $90 \mathrm{~min}$. 
(Figure 15). Pectinase of the isolated bacterium is superior in terms of the thermal stability from pectinase of Bacillus subtilis CM5 and Bacillus sp. MG-cp-2 (Kapoor et al., 2000; Ray, 2010) ie. $80 \%$ at $70{ }^{\circ} \mathrm{C}$ for $30 \mathrm{~min}$ and $50 \%$ for 20 min at $80^{\circ} \mathrm{C}$ respectively.

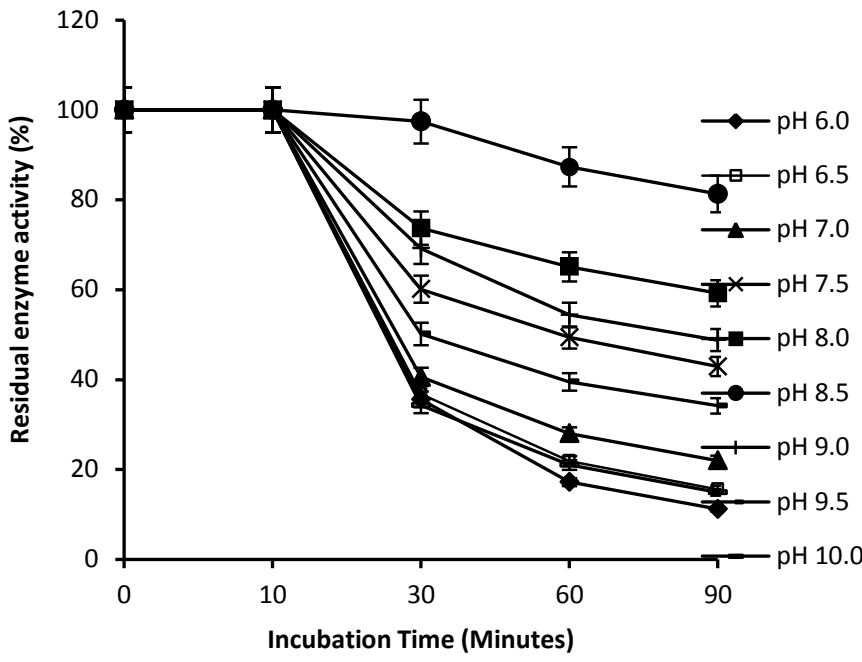

Figure 14 Stability of pectinase in acidic to alkaline $\mathrm{pH}$ scale

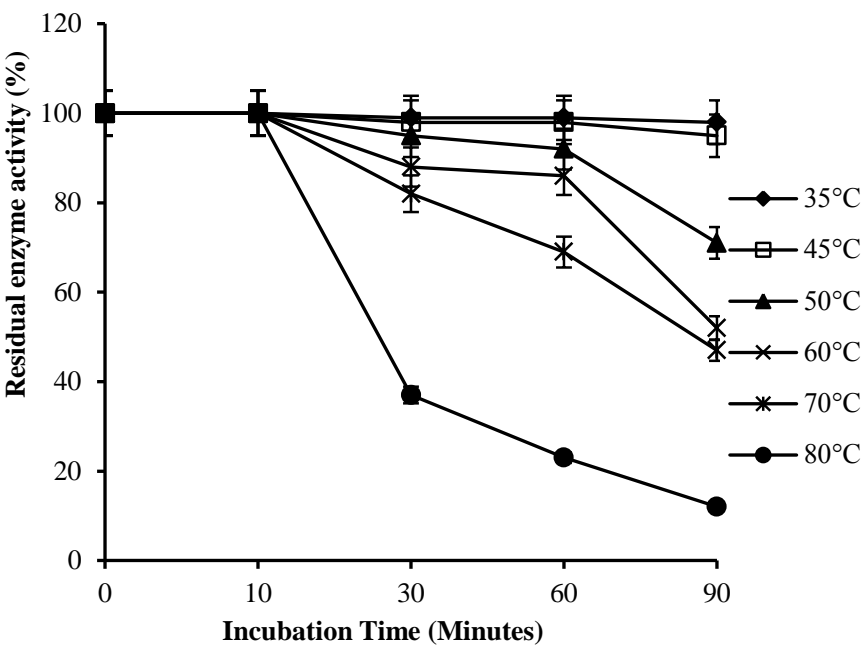

Figure 15 Thermostability of pectinase at various temperature scales

\section{Enzymatic pretreatment of Kraft pulp $\left(\mathbf{E}_{0}\right)$}

The drop in kappa number after enzyme pretreatment indicates the inputs of the enzymes in the bleaching of paper pulp. No remarkable changes in kappa number were observed by the treatment with set-I that comprises $10 \mathrm{IU}$ of pectinase and $1.8 \mathrm{IU}$ of xylanase per gram of OD pulp. Whereas, treatment with set-II containing $15 \mathrm{IU}$ of pectinase and $2.7 \mathrm{IU}$ of xylanase per gram of OD pulp reduced the Kappa number by 1.94 unit (Table 10) as compared to the control (untreated pulp) and that is nearly double the \% reduction than the report of Thakur et al., (2012). So due to the good result with set-II, it had been channelized for detail study in chemical bleaching process to reduce the load of the chemical bleach agent

Table 10 Characterization of enzyme $\left(\mathrm{E}_{0}\right)$ pretreated and untreated (Control) unbleached pulps

\begin{tabular}{llll}
\hline Particulars & Control & \multicolumn{2}{l}{ Enzyme $\left(\mathbf{E}_{\mathbf{0}}\right)$ treated pulp } \\
\hline Enzyme dose (IU.gm $\left.^{-1}\right)$ & Nil & Set-I & Set-II \\
\hline Kappa no. of pulp & 24.55 & 23.07 & 22.61 \\
\hline Brightness (\% ISO) & 24.12 & 24.24 & 24.77 \\
\hline Yellowness (\%ISO) & 40.88 & 40.91 & 40.80 \\
\hline
\end{tabular}

\section{Bleaching of Pulp $\left(\mathrm{D}_{0}\right.$-Ep- $\left.\mathrm{D}_{1}\right)$}

The values of improvement in brightness and whiteness of pulp at different sequential stages ranging from $\mathrm{ClO}_{2}$ stage $\left(\mathrm{D}_{0}\right)$ to Alkali Extraction $\left(\mathrm{E}_{\mathrm{p}}\right)$ Stage and up to $\mathrm{ClO}_{2}$ stage $\left(\mathrm{D}_{1}\right)$ stage of chemical bleaching was determined. Enzyme pretreatment with pectino-xylanolytic preparation showed a reduction in Kappa Number by 1.94 units and increment in \% ISO brightness by 1.32 units with setII at $50^{\circ} \mathrm{C}$ temperature and $\mathrm{pH} 8.0$ for $120 \mathrm{~min}$ (Table 11). Our result of a reduction in Kappa Number and increment in \% ISO brightness is far better than earlier study (Ahlawat et al., 2007). Moreover, the combined use of pectinase and xylanase are more preferable approach than single enzymes for kraft pulp pretreatment (Dhiman et al., 2009) because the treatment with the pectinase lowers the cationic demand of the pulp and xylanase predominantly delignify the pulp. Treatment of the kraft pulp with pectino-xylanolytic enzymes extracted from the isolate resulted in $15 \%$ less chlorine consumption to obtain the same optical property of the pulp as attained with conventional chemical bleaching. Therefore, this renders the process eco-friendly and sustainable. The outcome of the bleaching after a $\mathrm{D}_{0}-\mathrm{E}_{\mathrm{p}}-\mathrm{D}_{1}$ stage in properties of pulp seemed to be suitable for commercial exploration.

$\underline{\text { Table } 11 \mathrm{D}_{0}-\mathrm{E}_{\mathrm{p}}-\mathrm{D}_{1} \text { bleaching of enzyme treated and untreated pulps }}$

\begin{tabular}{|c|c|c|c|c|}
\hline \multirow{3}{*}{$\begin{array}{l}\text { Sr. } \\
\text { No. }\end{array}$} & \multirow{3}{*}{ Particulars } & \multirow{3}{*}{ Control } & \multicolumn{2}{|c|}{ Enzyme treated Set-II } \\
\hline & & & & \\
\hline & & & Same dose & $\begin{array}{l}15 \% \text { less } \\
\text { dose }\end{array}$ \\
\hline \multirow[t]{5}{*}{1} & \multicolumn{4}{|c|}{$\mathrm{ClO}_{2}$ stage $\left(\mathrm{D}_{0}\right)$} \\
\hline & Applied chlorine, $\%$ & 6.47 & 6.47 & 5.50 \\
\hline & Brightness, \% ISO & 50.34 & 50.80 & 44.91 \\
\hline & Yellowness, \%ISO & 36.21 & 32.37 & 35.18 \\
\hline & Whiteness \%ISO & ND & ND & ND \\
\hline \multirow[t]{6}{*}{2} & \multicolumn{4}{|c|}{ Alkali Extraction $\left(\mathrm{E}_{\mathrm{p}}\right)$ Stage } \\
\hline & Applied $\mathrm{NaOH}, \%$ & 2.5 & 2.5 & 2.5 \\
\hline & Applied Peroxide, $\%$ & 1.0 & 1.0 & 1.0 \\
\hline & Brightness, \% ISO & 72.46 & 75.00 & 69.10 \\
\hline & Yellowness, \%ISO & 19.41 & 15.68 & 19.80 \\
\hline & Whiteness \%ISO & 38.06 & 45.00 & 33.39 \\
\hline \multirow[t]{6}{*}{3} & \multicolumn{4}{|c|}{$\mathrm{ClO}_{2}$ stage $\left(\mathrm{D}_{1}\right)$} \\
\hline & Applied chlorine, $\%$ & 4.31 & 4.31 & 4.31 \\
\hline & Brightness, \% ISO & 88.58 & 89.90 & 89.12 \\
\hline & Yellowness, \%ISO & 7.60 & 7.77 & 8.32 \\
\hline & Whiteness \%ISO & 75.71 & 76.61 & 75.18 \\
\hline & $\begin{array}{c}\text { Brightness } \\
\text { Improvement Unit }\end{array}$ & - & 1.32 & 0.56 \\
\hline
\end{tabular}

\section{Analysis of treated pulp}

The pulp viscosity of enzymes treated Set-II pulp after the $D_{0}-E_{p}-D_{1}$ stage was 586.67 , which was very close to the 581.82 value of enzyme untreated pulp. The viscosity of treated pulp clearly indicated there was no destruction of the cellulosic fibers. Nearly $15 \%$ reduction in post color number (P C Number) of enzyme treated pulp was transpired. Furthermore, after the pulp bleaching process, the chemical analysis of pulp-free filtrate was performed and it divulged the noteworthy enhancement in the release of colour $\left(6.36 \mathrm{Kg}_{\mathrm{tp}}{ }^{-1}\right)$, phenolics (35.77 Kg.tp $\left.{ }^{-1}\right)$ and lignin $\left(1.15 \mathrm{Kg}_{\mathrm{tp}}{ }^{-1}\right)$ as compared to the control. The release of total reducing sugar also supports the investigation (Table 12). Removal of color, phenolic and lignin with the release of reducing sugars is the indirect assessment to check the efficiency of bleaching using enzymes (Saleem $\boldsymbol{e t}$ al., 2009).

\section{Effects of enzymes treatment on paper quality}

Canadian standard freeness enhancement from 280 in untreated to 310 in enzyme treated pulp is the perfect proof of better strength. The gain in Double fold number $(3.2 \%)$ indicated the improvement in the endurance of paper. Minor variations in Burst index, Tensile index and Tear index of enzyme treated pulp reflected the conservation of pulp properties (Table 13). The result of paper quality testing reflects that the pulp fibrillation, water retention and restoration of fiber bonding are unaffected (Gupta et $\boldsymbol{a l}$., 2000). Ours is a novel combinatorial approach where the mixture of enzymes is predominated by pectinase rather than xylanase. Nevertheless comparable result was achieved by Dhiman et al., (2009). 
Table 12 Analysis of pulp filtrates of enzyme treated \& untreated pulp samples

\begin{tabular}{|c|c|c|c|c|}
\hline Sample Code & $\begin{array}{c}\text { TRS } \\
\text { Kg.tp }^{-1}\end{array}$ & $\begin{array}{c}\text { Colour } \\
\text { at } \\
(465 n m) \\
\text { Kg.tp }^{-1}\end{array}$ & $\begin{array}{c}\text { Lignin at } \\
(280 n m) \\
\text { Kg.tp }^{-1}\end{array}$ & $\begin{array}{c}\text { Phenolics } \\
\text { at }(237 \\
\text { nm) } \\
\text { Kg.tp }^{-1}\end{array}$ \\
\hline Control & 0.15 & 5.27 & 0.62 & 20.88 \\
\hline Enzyme treated (Set-I) & 0.17 & 9.23 & 1.31 & 42.75 \\
\hline Enzyme treated (Set-II) & 0.20 & 11.64 & 1.77 & 56.65 \\
\hline
\end{tabular}

Table 13 Strength properties of enzyme treated and untreated bleached pulp

\begin{tabular}{lcc}
\hline Particulars & Control & Enzyme pretreated (Set-II) \\
\hline Canadian Standard Freeness & 280 & 310 \\
\hline Double Fold & 75 & 77.50 \\
\hline Burst index $\left(\mathrm{Pa} \cdot \mathrm{m}^{2} \cdot \mathrm{g}^{-1}\right)$ & 3.88 & $3.44(11.3 \%)$ \\
\hline Tensile index $\left(\mathrm{Nm} \cdot \mathrm{g}^{-1}\right)$ & 58.65 & $56.10(4.34 \%)$ \\
\hline Tear index $\left(\mathrm{Nm} \cdot \mathrm{m}^{2} \cdot \mathrm{g}^{-1}\right)$ & 6.73 & 6.40 \\
\hline
\end{tabular}

\section{CONCLUSION}

The isolated B. firmus produced the substantial amount of pectinase and limited xylanase along with negligible cellulase, the enzyme combination worth exploring in pulp pretreatment. Yeast extract and orange peel were screened out as preferred nitrogen source and raw agri-residues respectively using one variable at-a-time approach. More than $17 \%$ improvement in pectinase production suggest the successful optimization using RSM and in this way render the process more viable for mass production of pectinase. Enzyme properties concerning the range of optimal $\mathrm{pH}$, temperature and different cationic metals warrant its potentia biotechnological practice. The predominant use of pectinase rather than xylanase in combinatorial approach for pulp pretreatment and subsequent analysis of pulp and paper quality yielded an equivalent result to the well-studied approach comprising more xylanase and less pectinase. The lessening of chlorine consumption on account of enzymatic pretreatment eventually leads to a reduction in chlorinated aromatic compounds in the effluent makes it easier to embrace the green technologies in paper industries. Therefore, the bacterial pectinase with thermo-alkalistable nature having the noteworthy ability to reduce the kappa number and increase the brightness of kraft pulp warrants the further investigation for a new horizon.

Acknowledgments: The authors gratefully acknowledge the technical support provided by Central Pulp and Paper Research Institute, Saharanpur, India.

\section{REFERENCES}

Adhyaru, D. N., Bhatt, N. S., \& Modi, H. A. (2014). Enhanced production of cellulase-free, thermo-alkali-solvent-stable xylanase from Bacillus altitudinis DHN8, its characterization and application in sorghum straw saccharification. Biocatalysis and Agricultural Biotechnology, 3(2), 182-190. http://dx.doi.org/10.1016/j.bcab.2013.10.003

Ahlawat, S., Battan, B., Dhiman, S. S., Sharma, J., \& Mandhan, R. P. (2007) Production of thermostable pectinase and xylanase for their potential application in bleaching of kraft pulp. Journal of Industrial Microbiology \& Biotechnology, 34(12), 763-770. http://dx.doi.org/10.1007/s10295-007-0251-3

Ali, S. B. R., Muthuvelayudham, R., \& Viruthagiri, T. (2013). Statistical optimization of medium components for hemicellulase production using tapioca stem. Journal of Microbiology, Biotechnology and Food Sciences, 2(6), $2377-$ 2382 .

Aravantinos-Zafiris, G., Oreopoulou, V., Tzia, C., \& Thomopoulos, C. D. (1994). Fibre Fraction from Orange Peel Residues after Pectin Extraction. LWT - Food $\begin{array}{lll}\text { Science } \quad \text { and } & \text { 27(5), }\end{array}$ http://dx.doi.org/10.1006/fstl.1994.1094

Bailey, M. J., Biely, P., \& Poutanen, K. (1992). Interlaboratory testing of methods for assay of xylanase activity. Journal of Biotechnology, 23(3), 257 270.http://dx.doi.org/10.1016/0168-1656(92)90074-J

Basu, S., Ghosh, A., Bera, A., Saha, M. N., Chattopadhyay, D., \& Chakrabarti, K. (2008). Thermodynamic characterization of a highly thermoactive extracellular pectate lyase from a new isolate Bacillus pumilus DKS1.

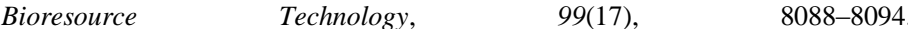
http://dx.doi.org/10.1016/j.biortech.2008.03.032

Cao, J., Sun, W., Pan, Y., \& Chen, S. (2000). High-Producers of Polygalacturonase Selected From Mutants Resistant to Rifampin in Alkalophilic Bacillus sp. NTT33. Enzyme and Microbial Technology, 27(8), 545-548. http://dx.doi.org/10.1016/S0141-0229(00)00200-3

Chapla, D., Divecha, J., Madamwar, D., \& Shah, A. (2010). Utilization of agroindustrial waste for xylanase production by Aspergillus foetidus MTCC 4898 under solid state fermentation and its application in saccharification. Biochemical Engineering Journal, 49(3),

361-369. http://dx.doi.org/10.1016/j.bej.2010.01.012

Choudhury, B., Chauhan, S., Singh, S. N., \& Ghosh, P. (2006). Production of Xylanase of Bacillus coagulans and its bleaching potential. World Journal of
Microbiology and Biotechnology,

$22(3)$

$283-288$ http://dx.doi.org/10.1007/s11274-005-9033-0

Dhiman, S. S., Garg, G., Mahajan, R., Garg, N., \& Sharma, J. (2009). "Single lay out" and "mixed lay out" enzymatic processes for bio-bleaching of kraft pulp. $\begin{array}{lll}\text { Bioresource } & \text { Technology, } & \text { 4736-4741. }\end{array}$ http://dx.doi.org/10.1016/j.biortech.2009.04.059

El-Shishtawy, R. M., Mohamed, S. A., Asiri, A. M., Gomaa, A. M., Ibrahim, I. H., \& Al-Talhi, H. A. (2014). Solid fermentation of wheat bran for hydrolytic enzymes production and saccharification content by a local isolate Bacillus megatherium. BMC Biotechnology, 14(1), 1-8. http://dx.doi.org/10.1186/1472 6750-14-29

Embaby, A. M., Masoud, A. A., Marey, H. S., Shaban, N. Z., \& Ghonaim, T. M. (2014). Raw agro-industrial orange peel waste as a low cost effective inducer for alkaline polygalacturonase production from Bacillus licheniformis SHG10. SpringerPlus, 3(1), 1-13. http://dx.doi.org/10.1186/2193-1801-3-327

Ersayin Yasinok, A., Biran, S., Kocabas, A., \& Bakir, U. (2010). Xylanase from a soil isolate, Bacillus pumilus: gene isolation, enzyme production, purification, characterization and one-step separation by aqueous-two-phase system. World Journal of Microbiology and Biotechnology, 26(9), 1641-1652. http://dx.doi.org/10.1007/s11274-010-0340-8

Gangwar, A. K., Prakash, N. T., \& Prakash, R. (2014). Applicability of Microbial Xylanases in Paper Pulp Bleaching: A Review. BioResources, 9(2), 3733-3754. http://dx.doi.org/10.15376/biores.9.2.3733-3754

Gavrilescu, M., \& Chisti, Y. (2005). Biotechnology-a sustainable alternative for chemical industry. Biotechnology Advances, 23(7-8), 471-499. http://dx.doi.org/10.1016/j.biotechadv.2005.03.004

Gharpuray, M. M., Lee, Y. H., \& Fan, L. T. (1983). Structural modification of lignocellulosics by pretreatments to enhance enzymatic hydrolysis. Biotechnology and Bioengineering, 25(1), 157-172. http://dx.doi.org/10.1002/bit.260250113

Ghose, T. K. (1987). Measurement of Cellulase Activities. Pure and Applied Chemistry, 59(2), 257-268. http://dx.doi.org/10.1351/pac198759020257

Gupta, S., Bhushan, B., \& Hoondal, G. S. (2000). Isolation, purification and characterization of xylanasefrom Staphylococcus sp. SG-13 and its application in biobleaching of kraft pulp. Journal of Applied Microbiology, 88(2), 325-334. http://dx.doi.org/10.1046/j.1365-2672.2000.00974.x

Kapoor, M., Beg, Q. K., Bhushan, B., Singh, K., Dadhich, K. S., \& Hoondal, G. S. (2001). Application of an alkaline and thermostable polygalacturonase from Bacillus sp. MG-cp-2 in degumming of ramie (Boehmeria nivea) and sunn hemp (Crotalaria juncea) bast fibres. Process Biochemistry, 36(8-9), 803-807. http://dx.doi.org/10.1016/S0032-9592(00)00282-X

Kapoor, M., Khalil Beg, Q., Bhushan, B., Dadhich, K. S., \& Hoondal, G. S (2000). Production and partial purification and characterization of a thermo-alkali stable polygalacturonase from Bacillus sp. MG-cp-2. Process Biochemistry 36(5), 467-473. http://dx.doi.org/10.1016/S0032-9592(00)00238-7

Kashyap, D. R., Soni, S. K., \& Tewari, R. (2003). Enhanced production of pectinase by Bacillus sp. DT7 using solid state fermentation. Bioresource Technology, 88(3), 251-254. http://dx.doi.org/10.1016/S0960-8524(02)00206-7 Kaur, A., Mahajan, R., Singh, A., Garg, G., \& Sharma, J. (2010). Application of cellulase-free xylano-pectinolytic enzymes from the same bacterial isolate in biobleaching of kraft pulp. Bioresource Technology, 101(23), 9150-9155. http://dx.doi.org/10.1016/j.biortech.2010.07.020

Kobayashi, T., Higaki, N., Yajima, N., Suzumatsu, A., Hagihara, H., Kawai, S., $\&$ Ito, S. (2001). Purification and properties of a galacturonic acid-releasing exopolygalacturonase from a strain of Bacillus. Bioscience, Biotechnology, and Biochemistry, 65(4), 842-847. http://dx.doi.org/10.1271/bbb.65.842

Kumar, L., Kumar, D., Nagar, S., Gupta, R., Garg, N., Kuhad, R. C., \& Gupta, V. K. (2013). Modulation of xylanase production from alkaliphilic Bacillus pumilus VLK-1 through process optimization and temperature shift operation. 3 Biotech, 4(4), 345-356. http://dx.doi.org/10.1007/s13205-013-0160-2

Lahtinen, M., Kruus, K., Boer, H., Kemell, M., Andberg, M., Viikari, L., \& Sipilä, J. (2009). The effect of lignin model compound structure on the rate of oxidation catalyzed by two different fungal laccases. Journal of Molecular $\begin{array}{llll}\text { Catalysis } & \text { B: } & \text { Enzymatic, } & \text { 204-210 }\end{array}$ http://dx.doi.org/10.1016/j.molcatb.2008.09.004

M.P.Kusuma and D. Sri Rami Reddy. (2014). Purification and Characterization of Polygalacturonase using Isolated Bacillus subtilis C-4. Research Journal of Microbiology, 9(2), 95-103. http://dx.doi.org/10.3923/jm.2014.95.103

Martín, M. A., Fernández, R., Serrano, A., \& Siles, J. A. (2013). Semi-continuous anaerobic co-digestion of orange peel waste and residual glycerol derived from biodiesel manufacturing. Waste Management, 33(7), 1633-1639. http://dx.doi.org/10.1016/j.wasman.2013.03.027

Miller, G. L. (1959). Use of Dinitrosalicylic Acid Reagent for Determination of Reducing Sugar. Analytical Chemistry, 31(3), 426-428. http://dx.doi.org/10.1021/ac60147a030

Nagar, S., Gupta, V. K., Kumar, D., Kumar, L., \& Kuhad, R. C. (2010) Production and optimization of cellulase-free, alkali-stable xylanase by Bacillus pumilus SV-85S in submerged fermentation. Journal of Industrial Microbiology and Biotechnology, 37(1), 71-83. http://dx.doi.org/10.1007/s10295-009-0650-8 
Plackett, R. L., \& Burman, J. P. (1946). The design of optimum multifactorial experiments. Biometrika, 33(4), 305-325. http://doi.org/10.1093/biomet/33.4.305

Poondla, V., Bandikari, R., Subramanyam, R., \& Reddy Obulam, V. S. (2015) Low temperature active pectinases production by Saccharomyces cerevisiae isolate and their characterization. Biocatalysis and Agricultural Biotechnology, 4(1), 70-76. http://dx.doi.org/10.1016/j.bcab.2014.09.008

Ratanakhanokchai, K., Noiduang, P., \& Kyu, K. L. (2002). Two extracellula endoxylanases from alkaliphilic Bacillus firmus differ in their synthesis. Biotechnology Letters, $\quad 24(18), \quad 1487-1490$. http://dx.doi.org/10.1023/A:1019895929283

Ray, M. R. S. and R. C. (2010). Production, Characterization and Application of a Thermostable Exo- polygalacturonase by Bacillus subtilis CM5. Food Biotechnology, 24(July), 37-50. http://dx.doi.org/10.1080/08905430903320958

Rehman, H. U., Qader, S. A. U., \& Aman, A. (2012). Polygalacturonase: production of pectin depolymerising enzyme from Bacillus licheniformis KIBGE IB-21. Carbohydrate Polymers, 90(1), 387-391. http://dx.doi.org/10.1016/j.carbpol.2012.05.055

Reid, I., \& Ricard, M. (2000). Pectinase in papermaking: solving retention problems in mechanical pulps bleached with hydrogen peroxide. Enzyme and Microbial Technology, 26(2-4), 115-123. http://dx.doi.org/10.1016/S01410229(99)00131-3

Rivas, B., Torrado, A., Torre, P., Converti, A., \& Domínguez, J. M. (2008)

Submerged citric acid fermentation on orange peel autohydrolysate. Journal of Agricultural and Food Chemistry, 56(7), 2380-2387. http://dx.doi.org/10.1021/jf073388r

Roosdiana, A., Prasetyawan, S., \& Mahdi, C. (2013). Production and Characterization of Bacillus firmus Pectinase. The Journal of Pure and Applied Chemistry Research, 2(April), 35-41.

Saleem, M., Tabassum, M. R., Yasmin, R., \& Imran, M. (2009). Potential of xylanase from thermophilic Bacillus sp. XTR-10 in biobleaching of wood kraf pulp. International Biodeterioration \& Biodegradation, 63(8), 1119-1124. http://dx.doi.org/10.1016/j.ibiod.2009.09.009

Sanaa, M. A., Zeinab, M. H. K., Ahmed, I. E., \& Dina, a. M. (2014). Production, purification and characterization of polysaccharide lytic enzymes of a marine isolate, Bacillus cereus NRC-20 and their application in biofilm removal. African Journal of Microbiology Research, 8(26), 2492-2504. http://dx.doi.org/10.5897/AJMR12.953

Sharma, D. C., \& Satyanarayana, T. (2006). A marked enhancement in the production of a highly alkaline and thermostable pectinase by Bacillus pumilus dcsr1 in submerged fermentation by using statistical methods. Bioresource Technology, 97(5), 727-733. http://dx.doi.org/10.1016/j.biortech.2005.04.012

Sharma, D. C., \& Satyanarayana, T. (2012). Biotechnological Potential of Agro Residues for Economical Production of Thermoalkali-Stable Pectinase by Bacillus pumilus desr1 by Solid-State Fermentation and Its Efficacy in the Treatment of Ramie Fibres. Enzyme Research, 2012, 1-7. http://dx.doi.org/10.1155/2012/281384

Sumathi, S., \& Hung, Y.-T. (2006). Treatment of pulp and paper mill wastes. Waste Treatment in the Process Industries, 453-497.

Thakur, V. V., Jain, R. K., \& Mathur, R. M. (2012). Studies on xylanase and laccase enzymatic prebleaching to reduce chlorine-based chemicals during $\mathrm{CEH}$ and ECF bleaching. BioResources, 7(2), 2220-2235. http://dx.doi.org/10.15376/biores.7.2.2220-2235

Thompson, G., Swain, J., Kay, M., \& Forster, C. F. (2001). The treatment of pulp and paper mill effluent: A review. Bioresource Technology, 77(3), 275-286. http://dx.doi.org/10.1016/S0960-8524(00)00060-2

Várnai, A., Huikko, L., Pere, J., Siika-Aho, M., \& Viikari, L. (2011). Synergistic action of xylanase and mannanase improves the total hydrolysis of softwood.
Bioresource
Technology,
102(19),
9096-9104.

http://dx.doi.org/10.1016/j.biortech.2011.06.059

Ververis, C., Georghiou, K., Danielidis, D., Hatzinikolaou, D. G., Santas, P., Santas, R., \& Corleti, V. (2007). Cellulose, hemicelluloses, lignin and ash content of some organic materials and their suitability for use as paper pulp supplements
Bioresource
Technology,
98(2),
296-301.

http://dx.doi.org/10.1016/j.biortech.2006.01.007

Viikari L, Tenakanen M, S. A. (2001). Biotechnology in the Pulp and Paper Industry. In Rehm HJ (Ed.), Biotechnology | Volume 10 (pp. 523-546). VCHWiley.

Viikari, L., Ranua, M., Kantelinen, A., Linko, M., \& Sundquist, J. (1987) Application of enzymes in bleaching. In Proceedings of 4th International Symposium on Wood and Pulping Chemistry, Paris (Vol. 1, pp. 151-154)

Viikari, L., Ranua, M., Kantelinen, A., Sundquist, J., \& Linko, M. (1986) Bleaching with enzymes. In Proceedings of 3rd International Conference on Biotechnology in the Pulp and Paper Industry, STFI, Stockholm (pp. 67-69).

Wood, P. J., Erfle, J. D., \& Teather, R. M. (1988). Use of complex formation between Congo Red and polysaccharides in detection and assay of polysaccharide hydrolases. Methods in Enzymology, (160C), 59-74. http://dx.doi.org/10.1016/0076-6879(88)60107-8

Zu-ming, L. I., Bo, J. I. N., \& Hong-xun, Z. (2008). Purification and Characterization of Three Alkaline Endopolygalacturonases from a Newly
Isolated Bacillus gibsonii. The Chinese Journal of Process Engineering, 8(4), 4 